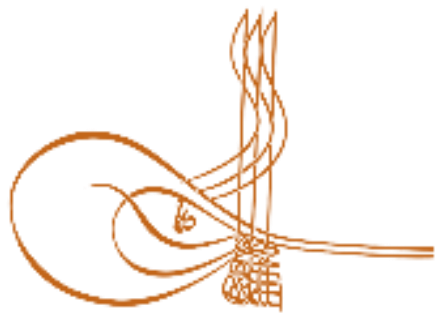

www.turkishstudies.net/education
Turkish Studies - Educational Sciences

eISSN: $2667-5609$

Research Article / Araşttrma Makalesi

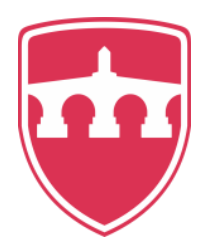

INTERNATIONAL

BALKAN

UNIVERSITY

Sponsored by IBU

\title{
Flüt Eğitiminde Aşamalı Kas Gevşeme Egzersizlerinin Öğrencilerin Performans Başarılarına Etkisi
}

\author{
The Effect of Progressive Muscle Relaxation Exercises in Flute Education on Students' \\ Performance Success
}

\author{
Burcu Akbulut Bilici* - Kübra Dilek Tankız** - Sadık Özçelik***
}

\begin{abstract}
In this study, it was aimed to determine the effect of progressive muscle relaxation exercises based on cognitive behavioral therapy in the field of psychotherapy on flute performance success of the students receiving Individual Instrument (Flute) Education. The study was conducted on the basis of a random pattern with a pretest-posttest control group, which is one of the real experimental research approaches. The study group of the research consists of undergraduate students $(n=10)$ at the 1 st grade who were studying at Gazi University Gazi Faculty of Education Fine Arts Education Department of Music Education in the spring semester of 2018-2019 academic year and started playing the flute at the first grade. During the 8-week experimental process, the flute teaching program based on progressive muscle relaxation exercises was applied to the experimental group and the traditional flute teaching program was implemented on the control group. Measurement performed over the same surveys (Gariboldi and Moyse's surveys) during the pretest and posttest stage including different technical and musical skills determined by taking expert opinions in order to identify the success levels of the experimental and control groups regarding their flute performances, were scored through the examination of the video records of student performances by 3 lecturers specialized in their fields. In the research, the data were obtained using the "Performance Assessment Form" created by the researcher in line with expert opinions. The obtained data were analyzed through SPSS 23.0. In the analysis of the data, after the interrater reliability $(\alpha)$, intraclass correlation coefficient, Kendall's W test results and the normal distribution were first examined, the Mann-Whitney U test, where mean ranks of small and independent groups
\end{abstract}

\footnotetext{
* Doktora Öğrencisi, Gazi Üniversitesi, Müzik Eğitimi

PhD Student, Gazi University, Music Education

ORCID 0000-0002-9670-4883

burcuakbulut1@hotmail.com

** Dr. Öğr. Üyesi, İnönü Üniversitesi, Eğitim Fakültesi, Güzel Sanatlar Eğitimi Bölümü

Asst. Prof. Dr. İnonu University, Faculty of Education, Department of Fine Arts Education

ORCID

dilek.tankiz@inonu.edu.tr

${ }_{* * * *}$ Prof. Dr. Gazi Üniversitesi, Gazi Eğitim Fakültesi, Güzel Sanatlar Eğitimi Bölümü

Prof. Dr. Gazi University, Gazi Faculty of Education, Department of Fine Arts Education

ORCID 0000-0001-6243-9957

scelik@gazi.edu.tr
}

Cite as/ Atıf: Akbulut Bilici, B., Tankız, K. D., Özçelik, S. (2020). Flüt eğitiminde aşamalı kas gevşeme egzersizlerinin öğrencilerin performans başarılarına etkisi, Turkish Studies - Education, 15(1), 529-548. https://dx.doi.org/10.29228/TurkishStudies.39983

Received/Geliş: 02 December/Aralık 2019

Accepted/Kabul: 25 February/Şubat 2020

Copyright $(C)$ INTAC LTD, Turkey

Checked by plagiarism software

Published/Yayın: 29 February/Şubat 2020

CC BY-NC 4.0 
were compared, was applied to compare the pretest scores of experimental and control groups before the implementation, and the Wilcoxon signed-rank test, where the means of the dependent groups were compared, was applied to compare the pretest and posttest scores of the experimental and control groups; the effect size (r) values were checked. According to the results of the research, it was concluded that the flute teaching based on progressive muscle relaxation exercises affected the performance success of the students in the experimental group positively and at a high level. When reviewed in terms of the dimensions $(n=12)$ comprising the flute performance success, a significant and high-level increase was observed in the dimensions $(\mathrm{n}=4)$ of "Ability to Use Abdominal Breathing Correctly and Efficiently", "Ability to Play the Notes Correctly" , "Ability to Play in Compliance with Rhythmic Patterns", “Ability to Play Play with Integrity and Correct Phrasing”. From Gariboldi and Moyse's surveys researching the effect on performance success, it was concluded that the significant difference appeared in the dimensions of "Ability to Use Abdominal Breathing Correctly and Efficiently", "Ability to Play the Notes Correctly”, "Ability to Obtain a Quality-Strong-Bright-Voluminous Tone”, "Ability to Practice Articulations Correctly”, "Ability to Use Fingers Smoothly”, "Ability to Play with Integrity and Correct Phrasing” ( $\mathrm{n}=6)$ in Moyse's survey scores affected the performance success positively and at a high level.

Structured Abstract: Introduction, Problem Status and Purpose: Performance anxiety is one the most fundamental problems encountered in musical instrument education. The level of anxiety experienced by the students, who have just learnt technical and musical skills, especially related to the instrument, during their instrumental performance may be higher as they have not had any concert or exam experiences before. When it is thought that symptoms such as increase in breathing rate, muscle strain, feeling nervous etc., which are among the symptoms of anxiety, may negatively affect the performance success specifically while playing the flute, which is a wind instrument, the investigation of how and at what level the progressive muscle relaxation exercises based on the cognitive behavioral therapy will affect the performance success of the students constitutes the main question of the research, because they aim at developing the breathing technique that leads the basic techniques related to playing the flute and decreasing the muscle strain. The question of this research, which aims at determining the aforementioned effect, was formed as "How do the progressive muscle relaxation exercises based on the cognitive behavioral therapy affect the performance success of the students in flute education?" Accordingly, the sub-questions of the research are stated as follows:

Group?

1. What is the descriptive value of the performance success and factor scores belonging to the Study

2. In terms of the progressive muscle relaxation exercises in flute education;

- Is there a significant difference in performance success pretest-posttest scores of the experimental and control groups?

- Is there a significant difference in performance success posttest scores of the experimental and control groups?

\section{Method}

The study was conducted on the basis of a random pattern with a pretest-posttest control group, which is one of the real experimental research approaches. The study group of the research consists of undergraduate students $(\mathrm{N}=10)$ at the 1st grade who were studying at Gazi University Gazi Faculty of Education Fine Arts Education Department of Music Education in the spring semester of 2018-2019 academic year and started playing the flute at the first grade. During the 8-week experimental process, the flute teaching program based on progressive muscle relaxation exercises was applied to the experimental group and the traditional flute teaching program was implemented on the control group. Measurement performed over the same surveys (Gariboldi and Moyse surveys) during the pretest and posttest stage including different technical and musical skills determined by taking expert opinions in order to identify the success levels of the experimental and control groups regarding their flute performance, were scored through the examination of the video records of student performances by 3 lecturers specialized in their fields. In the research, the data were obtained using the "Performance Assessment Form" created by the researcher in line with expert opinions.

\section{Data Analysis}

The obtained data were analyzed through SPSS 23.0. In the analysis of the data, after the interrater reliability $(\alpha)$, intraclass correlation coefficient, Kendall's W test results and the normal distribution were first 
examined, the Mann-Whitney U test, where mean ranks of small and independent groups were compared, was applied to compare the pretest scores of experimental and control groups before the implementation, and the Wilcoxon signed-rank test, where the means of the dependent groups were compared, was applied to compare the pretest and posttest scores of the experimental and control groups; the effect size (r) values were checked.

\section{Findings and Discussion}

In the analysis procedures, the total performance scores of 12 sub-dimensions were assessed over two surveys called Gariboldi Survey and Moyse Survey. It is clearly observed that the performance success of the experimental group increased significantly after the implementation. $[\mathrm{z}=-2.02, \mathrm{p}<.05]$. It was discovered that there was a significant difference in favor of positive ranks and the success of all the students in the experimental group increased. Thus, it can be said that progressive muscle relaxation exercises have a positive effect on flute performance success. In the study of BienAime (2011), it was found that the performance quality of the students increased after 3 sessions of solution-oriented short therapy implementations on music students. The findings obtained in the aforementioned research are in line with the results of this research.

According to Wilcoxon Signed -Rank test analysis, it was found that there was a significant difference in favor of the experimental group in the total performance scores of the experimental group before and after the implementation, and that the scores of all the 5 students in the experimental group regarding the dimensions "Ability to Use Abdominal Breathing Correctly and Efficiently", "Ability to Play the Notes Correctly", "Ability to Play in Compliance with Rhythmic Patterns", "Ability to Play with Integrity and Correct Phrasing" increased significantly after the flute teaching based on progressive muscle relaxation exercises. [ $\mathrm{z}=-2.02, \mathrm{p}<.05]$. The effect size was found to be high $[\mathrm{r}=.64>.50]$.

From Gariboldi and Moyse surveys researching the effect on the performance success, when the results of the analysis on Moyse survey pretest-posttest scores were evaluated, significant differences were discovered in favor of positive ranks, at a significant level in the dimensions of "Ability to Use Abdominal Breathing Correctly and Efficiently", "Ability to Play the Notes Correctly", "Ability to Obtain a Quality-Strong-Bright-Voluminous Tone", "Ability to Practice Articulations Correctly", "Ability to Use Fingers Smoothly", "Ability to Play with Integrity and Correct Phrasing" $[\mathrm{z}=-2.02, \mathrm{p}<.05]$. Effect size values were found to be high in all sub-dimensions with significance [r>.50]. As a result of the implementations of Lorenz's (2002) awareness and body adjustment studies based on Alexander's Technique, it was discovered that postures, breathing controls and voice technique of some subjects were positively affected while singing. The findings obtained from this study can be said to put forward an effective method for enhancing the technical skills of the students in their instrumental performance as in Lorenz's (2002) study.

\section{Conclusion and Suggestions}

According to the results of the research, it was concluded that the flute teaching based on progressive muscle relaxation exercises affected the performance success of the students in the experimental group positively and at a high level. When reviewed in terms of the dimensions $(\mathrm{N}=12)$ constituting the flute performance success, a significant and high-level increase was observed in the dimensions $(\mathrm{N}=4)$ "Ability to Use Abdominal Breathing Correctly and Efficiently", "Ability to Play the Notes Correctly", "Ability to Play in Compliance with Rhythmic Patterns","Ability to Play with Integrity and Correct Phrasing", however, no significant difference was discovered in the dimensions (N=8) "Ability to Obtain a Quality-Strong-Bright-Voluminous Tone", "Ability to Produce Clear Sound without Disrupting Intonation", "Ability to Practice Articulations Correctly", "Ability to Use Fingers Smoothly", "Ability to Practice Speed Terms", "Ability to Practice Nuance Terms", "Ability to Take Correct Postural Position", "Ability to Take Correct Holding Position".

From Gariboldi and Moyse surveys researching the effect on performance success, the significant difference in the dimensions (N=6) "Ability to Use Abdominal Breathing Correctly and Efficiently", "Ability to Play the Notes Correctly", "Ability to Obtain a Quality-Strong-Bright-Voluminous Tone", "Ability to Practice Articulations Correctly", "Ability to Use Fingers Fast", "Ability to Play in Harmony with Correct Compositions" in Moyse's survey scores affected the performance success at a high level.

In the light of the research results, the following suggestions are made.

Because the study has shown that progressive muscle relaxation exercises have a positive and high-level effect on students' success, it is suggested that they should be practiced in the fields of music education and 
instrumental education requiring performance. Moreover, flute educators are recommended to do these exercises before beginning abdominal activities.

It is suggested to include a course that will contribute to increasing the performance success of the students in departments of music education in terms of coping with performance anxiety and to raise their knowledge and awareness on this matter from young ages onward.

Generally, instrument educators are specifically recommended to make research on strategies to cope with performance anxiety and to raise the awareness of more students by both making use of their research in classes and holding seminars.

Keywords: Flute Education, Individual Instrumental Education, Performance Success, Performance Anxiety, Therapy.

Öz: Bu çalışmada; psikoterapi alanında yer alan bilişsel terapiye dayalı aşamalı kas gevşeme egzersizlerinin, Bireysel Çalg1 (Flüt) Eğitimi dersi alan öğrencilerin flüt performans başarılarına ekisinin tespit edilmesi amaçlanmıştır. Çalışma, gerçek deneysel araştırma yaklaşımlarından öntest-sontest kontrol gruplu seçkisiz desen temel alınarak gerçekleştirilmiştir. Araştırmanın çalışma grubunu, 2018- 2019 eğitim-öğretim yılının bahar döneminde, Gazi Üniversitesi Gazi Eğitim Fakültesi Güzel Sanatlar Eğitimi Bölümü Müzik Eğitimi Anabilim Dalı'nda öğrenim gören flüt çalmaya Lisans 1. sınıfta başlayan 1.sınıf flüt öğrencileri $(n=10)$ oluşturmaktadır. 8 haftalık deneysel işlem sürecinde deney grubuna aşamalı kas gevşeme egzersizlerine dayalı flüt öğretim programı; kontrol grubuna ise geleneksel flüt öğretim programı uygulanmıştır. Deney ve kontrol gruplarının flüt performansına ilişkin başarı düzeylerinin tespit edilmesi amacıyla uzman görüşleri alınarak belirlenen farklı teknik ve müzikal becerileri kapsayan öntest ve sontest aşamasında uygulanan aynı etütler (Gariboldi ve Moyse etütleri) üzerinden yapılan ölçümler, alan uzmanı 3 öğretim üyesi tarafindan öğrenci performanslarının video kayıtları incelenerek puanlandırılmıştır. Araştırmada veriler, araştırmacı tarafından uzman görüşleri doğrultusunda oluşturulan "Performans Değerlendirme Formu” kullanılarak elde edilmiştir. Elde edilen veriler, SPSS 23.0 programı ile analiz edilmiştir. Verilerin analizinde öncelikli olarak puanlayıcılar arası güvenirlik $(\alpha)$, sınıf içi korelasyon katsayısı, Kendall'W testi sonuçları ile normal dağılım özellikleri incelendikten sonra uygulama öncesi deney ve kontrol gruplarının öntest puanlarının karşılaştırılmasında küçük ve ilişkisiz grupların sıra ortalamalarının karşılaştırıldığı Mann-Whitney U testi; deney ve kontrol gruplarının öntest ve sontest puanlarının karşılaştırılmasında ise ilişkili grupların ortalamalarının karşılaştırıldığı Wilcoxon İşaretli Sıralar testi uygulanmış ve etki büyüklüğü (r) değerlerine bakılmıştır. Araştırmanın sonuçlarına göre; aşamalı kas gevşeme egzersizlerine dayalı flüt öğretiminin, deney grubu öğrencilerinin performans başarılarını olumlu yönde ve yüksek düzeyde etkilediği sonucuna ulaşılmıştır. Flüt performans başarısını oluşturan boyutlar $(\mathrm{n}=12)$ açısından bakıldığında ise "Diyafram Nefesini Doğru ve Verimli Kullanabilme", "Notaları Doğru Çalabilme" , "Ritim Kalıplarına Uygun Çalabilme", "Doğru Cümlemeler ile Bütünlük IÇerisinde Çalabilme" boyutlarında $(\mathrm{n}=4)$ anlamlı ve yüksek düzeyde artış olduğu saptanmıştır. Performans başarısı üzerinde etkisinin araştırıldığı Gariboldi ve Moyse etütlerinden; Moyse etütü puanlarında "Diyafram Nefesini Doğru ve Verimli Kullanabilme”, "Notaları Doğru Çalabilme”, "Kaliteli güçlü, parlak, hacimli - Ton Elde Edebilme”, "Artikülasyonları Doğru Bir Şekilde Uygulayabilme”, "Parmakları Akıcı Bir Şekilde Kullanabilme”, "Doğru Cümlemeler ile Bütünlük Iç̧erisinde Çalabilme” (n=6) boyutlarındaki anlamlı farklılığın, performans başarısına olumlu yönde ve yüksek düzeyde etki ettiği sonucuna ulaşıllmıştır.

Anahtar Kelimeler: Flüt Eğitimi, Bireysel Çalgı Eğitimi, Performans Başarısı, Performans Kaygısı, Terapi.

\section{Giriş}

Çalg1 eğitimi alan öğrencilerin çalgı performanslarına ilişkin başarıları, pek çok etkene bağlı olarak değişim göstermektedir. Özmenteş (2013)'e göre bu etkenlerden başlıcaları; düzenli çalışma, odaklanma, azim, özgüven, sabır ve rahat olabilme olarak sıralanmaktadır. Fakat bireysel farklılıklar dikkate alınarak yapılan çalgı eğitiminde, her öğrenciden tüm bu özelliklere sahip olmasını beklemek mümkün değildir. $\mathrm{Bu}$ yüzden, çalgı eğitimine yeni başlayan öğrencilerin bu özelliklerinin ortaya 
çıkmasına ve gelişmesine katkı sağlayacak destekleyici öğretim uygulamalarından yararlanmak öğrencilerin gelişimi açısından son derece önemlidir.

Özellikle flüt çalgısının nefesli bir çalgı olması sebebi ile sadece el ve parmakların değil; vücuttaki birçok organın (diyafram, boğaz, dil, dudak vb.) da kontrollü bir biçimde kullanılması gerekmektedir. Bu kriterlerin hepsini kontrollü bir şekilde yerine getirebilmek açısından icra sırasındaki rahatlık ve konsantrasyon oldukça önemlidir. Fakat bazı durumlarda bu hakimiyet mümkün olmayabilir. Özellikle flüt çalmaya yeni başlayan öğrencilerin hem performans başarısını etkileyen kişilik özelliklerine ilişkin davranışları kazanmaları hem de flüt performansları sırasında diyafram, nefes ve ağızlık hakimiyeti; dil ve parmak senkronizasyonu; notaları doğru çalma becerisi gibi çok fazla dikkat ve özen göstermeleri gereken kriterleri aynı anda yapabilme becerisini kazanmaları oldukça güç olabilmektedir.

Nefes tekniği, flüt çalmaya ilişkin tekniklerin en başında gelerek diğer tekniklere de temel oluşturmaktadır. Nefes tekniğinin gelişmesinde diyafram kası büyük öneme sahiptir. Diyafram nefesi, belli egzersizlerle oldukça iyi bir seviyeye ulaştırılabilir; ancak sadece, diyafram nefesi çalışmaları doğru bir nefes tekniği kazandırmada yeterli olmayabilir. Sağlam bir nefes tekniğine ilişkin gereklilikleri yerine getiremeyen bir öğrenciden parlak bir ton, akıcı bir parmak hızı ve temiz bir dil tekniği icra etmesi beklenemez. Ayrıca flütün, kamışlı bir çalgı olmamasından dolayı oktav seslerin oluşumu, sadece dudak pozisyonuyla sağlanmaktadır. Doğru bir nefes tekniği kazanmadan temiz ses elde etmenin mümkün olmadığ1 düşünüldüğünde; flüt eğitimcilerinin, öğrencilerine flüt çalmaya ilişkin mihenk taş1 sayılabilecek nefes tekniğine ilişkin gereklilikleri doğru bir şekilde kazandırmaları son derece önemlidir. Dural (2007), Önder (2013) ve Bilici (2014) de flüt eğitimcilerinin nefes tekniği üzerinde önemle durmas1 gerektiğine vurgu yaparak bu tekniğin mümkün olduğunca somutlaştırılarak öğrencilere aktarılması ve düzenli egzersizler yaptırılması gerektiğini savunmuşlardır.

Flüt eğitimine yeni başlayan öğrencilerde yaşanan sorunlardan biri, performans sırasında duyulan kaygıya bağlı olarak farkında olmadan kasların ve parmakların gereğinden fazla gerilmesi olarak belirtilebilir. Çalgı çalarken rahat çalmak hem fiziksel hem de duygusal açıdan çok önemlidir. Turgay (2002)'a göre bu rahatlık, kontrollü ve sistemli çalışma ile desteklendiği zaman entonasyon, vibrato ve nefes teknikleri açısından sorun oluşturmadığından, çalgı performansının daha rahat ve başarılı sergilenmesine katkı sağlamaktadır. Üstün (2010) ise, doğru bir çalışma alışkanlığı ile kazanılan becerilerin vücut rahatlığını kaybetmeden pekiştirilmesinin, flütte oluşabilecek teknik problemlerin önüne geçilmesi açısından büyük önem taşıdığını belirtmiştir.

Çalgı eğitiminde karşılaşılan temel sorunlar arasında performans çıktılarına ilişkin duyulan kaygının geldiği düşünüldüğünde; çalgıda teknik ve müzikal becerileri yeni öğrenen öğrencilerin çalgı performansları sırasında duymuş oldukları kaygı düzeyi, daha önce bir konser veya sınav deneyimi yaşamamış olmalarından dolayı daha yüksek olabilir. Müzik performans kaygısı olarak ele alınan bu durumu Tankız (2016), icracının çalgıya ilişkin teknik ve müzikal becerilerini, sınavlar ya da konserler esnasında sınav komisyonu veya izleyiciler karşısında sergilemesi sırasında kendi açısından anlam yüklediği çeşitli uyarıcılara (içsel-dışsal) karşı gösterdiği olumsuz psikolojik ve fizyolojik reaksiyonlar olarak tanımlamış ve kaygının fizyolojik ve psikolojik belirtileri arasında yer alan nefes alış-veriş hızının artması, kas gerginliği, gergin hissetme vb. belirtilerin üflemeli bir çalg1 olan flütün icrasını zorlaştırabileceğine ve performans kalitesine olumsuz etki edebileceğine vurgu yapmıştır. Bu açıdan bakıldığında performans başarısını olumsuz yönde etkileyebilen bu kaygı durumu ile başa çıkabilme açısından özelde, rahatlatıcı nefes egzersizlerinin ve kas gevşeme egzersizlerinin; genelde ise performans kaygısı ile başa çıkma stratejilerinin önemi ortaya çıkmaktadır. Ayrıca; YÖK (2018) tarafindan uygulamaya konulan merkezi "Müzik Öğretmenliği Lisans Programı" ders tanımları içerisinde yer alan Bireysel Çalgı (Flüt) Eğitimi dersinin içeriğine göre I,II ve III. Yarıyıllarda belirtilen kazanımlar arasında diyafram ve nefes çalışmalarına yer verilmiştir. Programda, öğrencilerin flüte ilişkin temel teknikleri kazanmasında ön koşul niteliğinde olan bu tekniklerin başlangıç aşamasında yer alması, nefes tekniğinin önemini ortaya koymaktadır. Bu noktalardan hareketle çalışmada, nefes ve kas gevşeme egzersizlerinin 
birlikte uygulandığı performans kaygısıyla başa çıkma yöntemlerinden biri olan ve psikoterapi alanında yer alan bilişsel-davranışçı terapiye dayalı "Aşamalı Kas Gevşeme Egzersizleri (AKGE)"nin, Bireysel Çalg1 (Flüt) Eğitimi dersi alan lisans 1. sınıf öğrencileri üzerinde uygulanmasının daha yararlı olacağı düşünülmüştür.

Yurt dışında performans kaygısıyla başa çıkma stratejilerinin, performans başarısı üzerinde etkisinin araştırıldığı çalışmalar ele alındığında aşamalı kas gevşeme egzersizleri (Appel, 1974; Kim, 2003), farkındalık/ rahatlama egzersizleri (Deen, 1999), alexander tekniği (Bosch, 1997; Hoberg, 2008; Lorenz, 2002), video modelleme hazırlığı (Rothlisberger,1992), performans kaygısı yönetimi eğitimi (Mansberger, 1988) ve çözüm odaklı kısa terapi uygulamaları (BienAime, 2011) üzerine yapılan deneysel çalışmalar ön plana çıkmaktadır. Bu çalışmaların yanı sıra yetenekli flüt öğrencilerinin başarılarını (Kenny, Fortune ve Ackermann, 2011) mesleki müzik eğitimi almış öğrencilerin başarılarını (Brotons, 1993) ve mükemmeliyetçi kişilik yapısına sahip olan müzisyenlerin başarılarını (Kobori, Yoshie, Kudo, Ohtsuki, 2011) performans kaygısı ile ilişkisel olarak inceleyen çalışmalar da karşımıza çıkmaktadır.

Yurt içinde yapılan çalışmalar incelendiğinde ise çalgı eğitiminde kaygı ile başa çıkma stratejilerinin, performans başarısı üzerinde etkisinin araştırıldığı deneysel bir çalışmaya rastlanmamıştır. Çok az sayıda çalışmada ise performans kaygısı ile başarı arasındaki ilişki, nedensel ve korelasyonel desenler temel alınarak incelenmiştir (Işkın, 2018; Umuzdaş, 2007; Yağışan, 2009). Oysa öğrencilerin çalgılarına ilişkin yaşadıkları sahne deneyimleri sırasında kaygı durumlarına bağlı olarak performans başarılarında azalmalar olabileceği düşünüldüğünde; performans kaygısı ile başa çıkma stratejlerinin, performans kalitesi üzerindeki etkilerinin ortaya konulması büyük önem taşımaktadır. Bu düşüncelerden hareketle, aşamalı kas gevşeme egzersizlerinin flüt çalmaya ilişkin temel tekniklere öncülük eden nefes tekniğini geliştirmeyi ve kaslardaki gerginliği azaltmayı amaçlayan çalışmalara dayanması bakımdan, öğrencilerin performans başarılarına ne yönde ve ne düzeyde etki edeceği, araştırmanın temel problem durumunu oluşturmaktadır. Bu araştırmada, Bilişsel-davranışçı terapiye dayalı aşamalı kas gevşeme egzersizlerinin, öğrencilerin flüt performans başarılarına etkisinin tespit edilmesi amaçlanmıştır. $\mathrm{Bu}$ doğrultuda, araştırmanın problem cümlesi "Flüt eğitiminde bilişsel-davranışçı terapiye dayalı aşamalı kas gevşeme egzersizlerinin öğrencilerin performans başarısı düzeyine etkisi nasıldır?" biçiminde oluşturulmuştur. Bu doğrultuda araştırmanın alt problemleri şu şekilde sıralanmıştır:

1. Çalışma Grubunun performans başarısı ve faktör puanlarının tanımlayıcı değeri nasıldır?

2. Flüt eğitiminde aşamalı kas gevşeme egzersizlerine göre;

- $\quad$ Deney ve kontrol gruplarının performans başarısı ön test- son test puanlarında

- Deney ve kontrol gruplarının performans başarısı son test puanlarında anlamlı bir fark var midir?

\section{Yöntem}

\subsection{Araştırmanın Modeli}

Nicel yapıdaki bu çalışma, gerçek deneysel araştırma yaklaşımlarından öntest-sontest kontrol gruplu seçkisiz desen temel alınarak gerçekleştirilmiştir. Öntest-sontest kontrol gruplu seçkisiz desenler; katılımcı havuzundan seçkisiz (yansız) bir biçimde deney ve kontrol gruplarına atamaların yapıldığı, etkililiği sınanacak işlemin sadece deney grubuna uygulandığı, uygulama öncesinde ve sonrasında aynı ya da eşdeğer ölçme araçlarının iki gruba uygulandığı araştırmalardır (Fraenkel, Wallen \& Hyun, 2011; Büyüköztürk, Kılıç Çakmak, Akgün, Karadeniz \& Demirel, 2016). $\mathrm{Bu}$ araştırmalarda, ilişkili ve ilişkisiz desen yapıları bir arada yer almaktadır. Deney ve kontrol gruplarının kendi içlerindeki aynı katılımcıların öntest ve sontest puanları arasındaki farklılıkları sınanarak, aynı ölçümün iki kez yapılması, bu yapıların ilişkili desenler olduğunu göstermektedir. Bununla birlikte farklı katılımcılardan oluşan deney grubunun öntest ve sontest ölçümleri ile kontrol grubunun öntest ve sontest ölçümleri arasındaki farkl1lıkların da test edilmesi, bu desenin aynı 
zamanda ilişkisiz bir yapıyı da bünyesinde barındırdığına işaret etmektedir. Buradan hareketle Howitt (1997) bu desenin karışık bir desen türü olduğunu ifade etmektedir (akt. Büyüköztürk vd., 2016).

Araştırmada, deney grubuna aşamalı kas gevşeme egzersizlerine dayalı flüt öğretim programı, kontrol grubuna ise geleneksel yaklaşım ile flüt öğretim programı uygulanmıştır. Tablo 1'de araştırmanın deseni görselleştirilerek verilmiştir.

Tablo 1: Öntest-Sontest Kontrol Gruplu Seçkisiz Desen

\begin{tabular}{|c|c|c|c|c|}
\hline \multirow{4}{*}{$\begin{array}{c}\text { Seçkisiz } \\
\text { seçilen } 10 \\
\text { öğrenci }\end{array}$} & Grup & Öntest & İşlem & Sontest \\
\hline & $D$ & $O_{1}$ & $X$ & $\mathrm{O}_{3}$ \\
\hline & $\begin{array}{l}\text { (5 öğrenci deney } \\
\text { grubu-seçkisiz) }\end{array}$ & $\begin{array}{l}\text { (Performans } \\
\text { değerlendirme } \\
\text { formu) }\end{array}$ & $\begin{array}{l}\text { (A. kas gevşeme } \\
\text { egzersizleri } \\
\text { dayalı öğrt. } \\
\text { prog.) }\end{array}$ & $\begin{array}{l}\text { ( Performans } \\
\text { değerlendirme } \\
\text { formu) }\end{array}$ \\
\hline & $\begin{array}{c}\boldsymbol{K} \\
\text { (5 ögrenci } \\
\text { kontrol grubu- } \\
\text { seçkisiz) }\end{array}$ & $\begin{array}{c}\boldsymbol{O}_{2} \\
\text { (Performans } \\
\text { değerlendirme } \\
\text { formu) }\end{array}$ & $\begin{array}{c}\boldsymbol{X} \\
\text { (Geleneksel } \\
\text { Öğretim } \\
\text { Programı) }\end{array}$ & $\begin{array}{c}\boldsymbol{O}_{4} \\
\text { ( Performans } \\
\text { değerlendirme } \\
\text { formu) }\end{array}$ \\
\hline
\end{tabular}

\section{2. Çalışma Grubu}

Araştırmanın çalışma grubunu, 2018- 2019 eğitim-öğretim yılının bahar döneminde, Gazi Üniversitesi Gazi Eğitim Fakültesi Güzel Sanatlar Eğitimi Bölümü Müzik Eğitimi Anabilim Dalı'nda öğrenim gören flüt çalmaya Lisans 1. sınıfta başlamış olan 1.sınıf flüt öğrencileri $(n=10)$ oluşturmaktadır. Bu doğrultuda katılımcılar seçkisiz (yansız) atama yöntemiyle seçilerek deney ve kontrol grupları oluşturulmuştur. Deney ve kontrol gruplarının; cinsiyet ve lise türüne göre dağılımları Tablo 2'de sunulmuştur.

Tablo 2: Deney ve Kontrol Gruplarının Cinsiyet ve Lise Türüne Göre Dağılımı

\begin{tabular}{ccccc} 
Grup & \multicolumn{2}{c}{ Cinsiyet } & \multicolumn{2}{c}{ Lise Türü } \\
& Kız (f) & Erkek (f) & GSL (f) & Diğer (f) \\
Deney & 4 & 1 & - & 5 \\
Kontrol & 3 & 2 & 2 & 3 \\
\hline
\end{tabular}

Tablo 2 incelendiğinde, kız öğrencilerin ve GSL dışındaki liselerden mezun olanların dağılım içerisinde baskın oldukları görülmektedir. Deney ve kontrol gruplarının uygulamaya başlamadan önce toplam performans başarısı ve boyutlarının puanlarındaki farklılıkların anlamlılık durumlarına ilişkin Mann-Whitney U testi sonuçları ise Tablo 3’te yer almaktadır. 
Tablo 3: Deney ve Kontrol Gruplarının Performans Başarısı ve Boyut Puanlarının Öntest Farklıklarının Mann-Whitney U Testi Sonuçları

\begin{tabular}{|c|c|c|c|c|c|c|c|c|}
\hline Puan Türü & Grup & $\mathbf{N}$ & S.O. & S. T. & $\mathbf{U}$ & $\mathbf{Z}$ & p & $\mathbf{r}$ \\
\hline \multirow{2}{*}{$\begin{array}{l}\text { Performans Başarısı } \\
\text { (Toplam) }\end{array}$} & Deney & 5 & 6.40 & 32.00 & \multirow{2}{*}{8.00} & \multirow{2}{*}{-.94} & \multirow{2}{*}{.35} & \multirow{2}{*}{ - } \\
\hline & Kontrol & 5 & 4.60 & 23.00 & & & & \\
\hline \multirow{2}{*}{$\begin{array}{l}\text { Diyafram Nefesini Doğru } \\
\text { ve Verimli Kullanabilme }\end{array}$} & Deney & 5 & 7.00 & 35.00 & \multirow{2}{*}{5.00} & \multirow{2}{*}{-1.57} & \multirow{2}{*}{.12} & \multirow{2}{*}{ - } \\
\hline & Kontrol & 5 & 4.00 & 20.00 & & & & \\
\hline \multirow{2}{*}{ Notaları Doğru Çalabilme } & Deney & 5 & 6.60 & 33.00 & \multirow{2}{*}{7.00} & \multirow{2}{*}{-1.16} & \multirow{2}{*}{.25} & \multirow{2}{*}{ - } \\
\hline & Kontrol & 5 & 4.40 & 22.00 & & & & \\
\hline \multirow{2}{*}{$\begin{array}{l}\text { Kaliteli -güçlü, parlak, } \\
\text { hacimli-Ton Elde } \\
\text { Edebilme }\end{array}$} & Deney & 5 & 7.10 & 35.50 & \multirow[b]{2}{*}{4.50} & \multirow[b]{2}{*}{-1.70} & \multirow[b]{2}{*}{.09} & \multirow[b]{2}{*}{ - } \\
\hline & Kontrol & 5 & 3.90 & 19.50 & & & & \\
\hline \multirow{2}{*}{$\begin{array}{l}\text { Entonasyonu Bozmadan } \\
\text { Temiz Ses Üretebilme }\end{array}$} & Deney & 5 & 6.90 & 34.50 & \multirow{2}{*}{5.50} & \multirow{2}{*}{-1.47} & \multirow{2}{*}{.14} & \multirow{2}{*}{ - } \\
\hline & Kontrol & 5 & 4.10 & 20.50 & & & & \\
\hline \multirow{2}{*}{$\begin{array}{l}\text { Artikülasyonları Doğru Bir } \\
\text { Şekilde Uygulayabilme }\end{array}$} & Deney & 5 & 6.30 & 31.50 & \multirow{2}{*}{8.50} & \multirow{2}{*}{-.85} & \multirow{2}{*}{.40} & \multirow{2}{*}{ - } \\
\hline & Kontrol & 5 & 4.70 & 23.50 & & & & \\
\hline \multirow{2}{*}{$\begin{array}{l}\text { Parmakları Akıcı Bir } \\
\text { Şekilde Kullanabilme }\end{array}$} & Deney & 5 & 6.60 & 33.00 & & & & \\
\hline & Kontrol & 5 & 4.40 & 22.00 & 7.00 & -1.16 & .25 & - \\
\hline Ritim Kalıplarına Uygun & Deney & 5 & 6.00 & 30.00 & & & & \\
\hline Çalabilme & Kontrol & 5 & 5.00 & 25.00 & 10.00 & -.53 & .60 & - \\
\hline Doğru Cümlemeler ile & Deney & 5 & 5.80 & 29.00 & & & & \\
\hline $\begin{array}{c}\text { Bütünlük İçerisinde } \\
\text { Çalabilme }\end{array}$ & Kontrol & 5 & 5.20 & 26.00 & 11.00 & -.32 & .75 & - \\
\hline Hiz Terimlerini & Deney & 5 & 6.40 & 32.00 & & & & \\
\hline Uygulayabilme & Kontrol & 5 & 4.60 & 23.00 & 8.00 & -.96 & .34 & - \\
\hline Nüans Terimlerini & Deney & 5 & 6.60 & 33.00 & 700 & 110 & 23 & 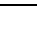 \\
\hline Uygulayabilme & Kontrol & 5 & 4.40 & 22.00 & 1.00 & -1.19 & .23 & - \\
\hline Doğru Duruş Pozisyonunu & Deney & 5 & 5.10 & 25.50 & & & & \\
\hline Uygulayabilme & Kontrol & 5 & 5.90 & 29.50 & 10.50 & -.42 & .67 & - \\
\hline Doğru Tutuş Pozisyonunu & Deney & 5 & 5.50 & 27.50 & 250 & 00 & & 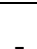 \\
\hline Uygulayabilme & Kontrol & 5 & 5.50 & 27.50 & 12.50 & .00 & 1.00 & - \\
\hline
\end{tabular}

Tablo 3’te görüldüğ̈̈ üzere, deney ve kontrol gruplarının deneysel işlemler öncesinde performans başarılarında anlamlı farklılık olmadığı görülmüştür [p>.05].

\subsection{Verilerin Toplanması}

Çalışma grubunu oluşturan Gazi Üniversitesi Eğitim Fakültesi Güzel Sanatlar Eğitimi Bölümü Müzik Eğitimi A.B.D. Lisans 1.sınıf flüt öğrencilerinin flüt performanslarının belirlenmesi amacıyla deney ve kontrol grubuplarına 8 hafta boyunca öğretim gerçekleştirilmiştir. Her iki gruba da deney öncesinde ve sonrasında ölçümler yapılmıştır. Araştırmada nicel verilerin elde edilebilmesi amacıyla başlangıç seviyesi flüt etütlerinin kısa etütlerden oluşmasından dolayı seviye, teknik ve müzikal becerilere ilişkin birçok kriteri aynı andan değerlendirebilmek amaciyla uzman görüşleri doğrultusunda flütte başlangıç seviyesine uygun olarak G.GARIBOLDI'nin "Die Ersten Übungen" kitabından 15 Numaralı Etüt, M. MOYSE'un "24 Petit Etudes Melodiques" kitabından 3 Numaralı Etüt olmak üzere iki ayrı etüt belirlenmiştir. Araştırmacı tarafindan hazırlanan ve uygulanacak olan "Aşamalı Kas Gevşeme Egzersizlerine Dayalı Bireysel Çalg1 Flüt Öğretim Programı" için tüm literatür taranarak öğrenci merkezli bir program tasarlanmıştır. İçeriği "hedef", "kazanımlar", "etkinlikler" ve "açıklamalar" başlıklarından oluşmaktadır. Deneysel işlemde uygulanacak olan flüt öğretimine ilişkin oluşturulan bu program; Anadolu Güzel Sanatlar Lisesi Türk ve Batı Müziği Çalgıları Dersi (flüt) Öğretim Programı'ndan (MEB, 2008) yararlanılarak, YÖK (2018) Müzik Öğretmenliği Lisans Programındaki Bireysel Çalgı (Flüt) Eğitimi dersinin içeriğine göre düzenlenmiştir. Aşamalı Kas Gevşeme Egzersizlerine dayalı oluşturulan flüt öğretim programının 
içeriğinde; duruş-tutuş, diyafram nefesi, ton kalitesi, artikülasyon, entonasyon, cümleleme, parmak tekniği becerilerine ilişkin kazanımlar bulunmaktadır.

Deneysel işlem öncesinde ve sonrasında öğrencilerin performans başarılarını belirlemek amacıyla yapılan ölçümlerde alanında uzman 3 öğretim üyesi tarafından "Uzman Görüşü Formu" ile alınan görüşler doğrultusunda araştırmacılar tarafından oluşturulmuş "Performans Değerlendirme Formu"na son şekli verilmiştir.

\subsection{Deneysel İşlem}

Deneysel işlem öncesinde ilk olarak aşamalı kas gevşeme egzersizlerinin nasıl yapılması gerektiği ile ilgili deney grubuna Gazi Üniversitesi Tıp Fakültesi Psikiyatri A.B.D. Öğretim Üyesi Prof. Dr. Selçuk Aslan tarafından örnek uygulama yaptırılmışırır. Bu bilgilendirme sonrasında, öntest için seçilmiş olan etütler öğrencilere çaldırılmış ve video ile kayıt altına alınmıştır.

Deney ve kontrol gruplarına uygulanan öntest aşamasından sonra araştırmacı tarafindan hazırlanmış olan "Aşamalı Kas Gevşeme Egzersizlerine Dayalı Bireysel Çalgı Flüt Öğretim Programı" ile 8 haftalık deneysel uygulamaya başlanmış, kontrol grubunda ise geleneksel öğretim yöntemi ile dersler devam etmiştir. Her iki grupla yapılan dersler haftanın 1 günü 45 'er dakikalık bir ders saati süresince gerçekleştirilmiştir. Deney grubuna AKGE uygulaması ile ilgili önceden verilmiş bilgiler doğrultusunda flüt derslerinde neler yapılacağ ile ilgili açıklamalarda bulunulmuştur. Deney grubuna, 8 hafta boyunca derse başlamadan önce AKGE uygulanmıș ve hemen ardından derse geçilmiştir. Derslerde; performans değerlendirme formuna ilişkin ölçütlerin tümünü kapsayacak şekilde teknik ve müzikal becerileri geliştirmeye yönelik olarak; Marcel Moyse- La Sonorité, Philippe Bernold- La Technique d'Embouchure, Trevor Wye- Practice Books 3, Articulation, Herbert Lindholm- Basic Flute Technique Periskuviot Huilulle kitaplarından egzersizler her ders düzenli olarak çalıştırılmış ve öğrencilerin dersteki performansları her ders video kamera ile kayıt altına alınmıştır.

Deney ve kontrol grupları ile yapılan 8 haftalık öğretim süreci sonunda öğrenciler, final sinavında son teste tabii tutulmuştur. Ön test ölçümlerinde olduğu gibi son test ölçümleri de aynı etütler üzerinden yapılarak öğrenci performansları, video kamera ile kayıt altına alınmıştır. Uygulama öncesi ve sonrası yapılan bu ölçümler, alan uzmanı 3 öğretim üyesi tarafından puanlanmıştır.

\subsection{Verilerin Analizi}

Performans değerlendirme toplam puanlarının belirlenmesi aşamasında üç puanlayıcıya ilişkin değerlerin ortalama değerleri tespit edilmiştir. Elde edilen verilerin 12 boyut ve 2 etüt için ayrı puan değerleri oluşturularak toplam performans başarısı puanları tespit edilmiştir.

Tanımlayıcı istatistikler ve analiz işlemlerine geçmeden önce puanlayıcılar arası güvenirlik ve uyum sorgulanmıştır. Bu amaç ile sınıf içi korelasyon katsayısı, iki yönlü rastgele etki modeli mutlak uyum (two-way random-absolute agreement) Cronbach Alpha $(\alpha)$ değerleri ve parametrik olmayan bir test niteliğindeki Kendall uyum katsayıları incelenmiştir (Can, 2016; Field, 2009). Bu değerler 1'e yaklaştıkça uyum düzeyi yükselmektedir (Can, 2016). Tablo 4'te puanlayıcıların uyum düzeylerine ilişkin analiz sonuçları yer almaktadır. 
Tablo 4: Puanlayıcıların Uyum Düzeylerinin Güvenirlik, Sınıf İçi Korelasyon ve Kendall’s W Testi Sonuçları

\begin{tabular}{lcccccccc}
\cline { 5 - 8 } & & & & \multicolumn{4}{c}{ Kendall's W } \\
\hline Puanlayic1 1 & 59.10 & 24.06 & & & & & \\
Puanlayic1 2 & 47.85 & 12.67 & $\mathbf{. 7 5}^{* *}$ & $\mathbf{. 9 3}$ & 3 & $\mathbf{. 9}^{* *}$ & 9 \\
Puanlayic1 3 & 55.65 & 18.18 & & & & & \\
\hline$* * p<.01$ & & & & & & &
\end{tabular}

Tablo 4'te görüldüğü üzere sınıf içi korelasyon katsayısının yüksek denilebilecek bir düzeyde bulunduğu tespit edilmiştir [r=.75, p<.01]. Kendall's W testi sonuçlarına bakıldığında üç puanlayıcı arasında yüksek düzeyde ve anlamlı derecede uyum olduğu ortaya çıkmıştır [W=.92, $\mathrm{p}<.01$ ] Puanların iç tutarlılığının ise yüksek düzeyde olduğu görülmektedir [ $\alpha=.93]$ Aritmetik ortalamalar ve standart sapmalar incelendiğinde; iki numaralı puanlayıcının, birinci ve üçüncü puanlayıcıya göre daha toleranssız, daha duyarlı ve tutarlı bir biçimde puan verdiği; birinci ve üçüncü puanlayıcıların ise ikinci puanlayıcıya göre daha geniş bir aralıkta, cömert bir yaklaşım sergiledikleri görülmüştür. Bu analizlerin bütününden hareketle, üç farklı puanlayıcının, 10 öğrenci için yaptıkları performans başarısına ilişkin değerlendirmelerin arasında anlamlı derecede, yüksek düzeyde güvenilir bir uyum olduğu düşünülmektedir.

Uyum ve güvenirlik analizlerinden sonra performans başarısı puanlarının normal dağılım özellikleri incelenmiştir. Bu amaçla öncelikle Shapiro-Wilk testi uygulanmıştır. Büyüköztürk (2008) grup büyüklügünün 50'den küçük olduğu, Ak (2008) ise grup büyüklüğünün 30'dan küçük olduğu durumlarda bu testin uygulanması gerekliliğine işaret etmektedir. Bu testin sonuçlarına göre sadece nüans, ritim ve artikülasyon puanlarında normallikten sapmalar olduğu görülmüştür. Çarpıklık ve basıklık değerlerinin standardize edilmiş z puanları (Field, 2009) incelendiğinde ise bütün değerlerin \pm 1.80 aralığında oldukları tespit edilmiştir. Standardize edilmiş çarpıklık ve basıklık puanlarının; Tabachnick ve Fidell (2007) \pm 3.29 , George ve Mallery (2010) \pm 2 , Büyüköztürk (2008) \pm 1 , Kalayc1 (2010) \pm 3 , Can (2016) \pm 1.96 aralığında olmasının normal dağılım için kabul edilebilir olduğu belirtmişlerdir. Her ne kadar Shapiro-Wilk ve çarpıklık-basıklık değerlerine göre değerlerin normallik için kabul edilebilir düzeyde olduğu görülse de, grup büyüklüğünün $(n=10) 30$ 'dan küçük olmasından dolayı normalliğin yeterli düzeyde olmadığı düşünülmüş ve araştırmada parametrik olmayan testlerin uygulanmasında karar kılınmıştır.

Tanımlayıcı istatistiklerin tespit edilmesi için aritmetik ortalama, standart sapma, en yüksek ve düşük değerler belirlenmiştir. Uygulama öncesi flüt performans başarısı puanlarındaki farklılıklar; küçük ve ilişkisiz grupların sıra ortalamalarının karşılaş̧ırıldığı Mann-Whitney U testi ile sınanmıştır (Field, 2009; Can, 2016; Büyüköztürk, 2008). Analiz işlemleri sonucunda grupların performans başarısı öntest puanlarında anlamlı farklılık olmadığı tespit edilmiştir. Deney ve kontrol gruplarının uygulama öncesi ve sonrası puanlarındaki farklılıkların tespit edilmesi için normalliğin yetersiz olduğu durumlarda ilişkili grupların ortalamalarının karşılaştırıldığı Wilcoxon İşaretli Sıralar testi uygulanmıştır (Field, 2009; Kalayc1, 2010; Can, 2016; Büyüköztürk, 2008). Öntest ve Sontest puanları arasındaki farklılıkların görselleştirilmesi için çizgi grafikleri oluşturulmuştur. Etki değerlerinin 1'e yaklaşması etkinin yükselmesi olarak yorumlanmış ve etki büyüklüklerinin saptanmasında ise $\mathrm{r}$ değerleri $z / \sqrt{(N \times 2)}$ formülü ile tespit edilmiştir. (Fritz, Morris ve Richler,

2012:12).

Turkish Studies - Education, 15(1) 


\section{Bulgular ve Yorumlar}

\section{1. Çalışma Grubunun Performans Başarısı ve Boyut Puanlarının Tanımlayı İstatistiklerine Yönelik Bulgular}

Bu alt başlıkta, çalıșmanın birinci alt problemine ilișkin bulgular sunulmuștur. Araștırmada veri toplama aracı olarak kullanılan performans değerlendirme formu toplam ve faktör puanlarının; aritmetik ortalama, standart sapma, en yüksek ve en düşük puan değerleri tespit edilmiştir. Tablo 5'te, öntest-sontest performans başarısı toplam ve boyut puanlarının tanımlayıcı değerleri sunulmuştur.

Tablo 5: Performans Başarısı Toplam ve Boyut Puanlarının Tanımlayıcı Değerleri

\begin{tabular}{|c|c|c|c|c|c|c|c|}
\hline & Puan Türü & Boyut & $\mathbf{N}$ & $\begin{array}{c}\text { En } \\
\text { Düşükk }\end{array}$ & $\begin{array}{c}\text { En } \\
\text { Yüksek }\end{array}$ & $\overline{\mathrm{x}}$ & SS \\
\hline \multirow{13}{*}{$\stackrel{\stackrel{\tilde{E}}{\mathscr{E}}}{: 0}$} & Toplam Performans Başarısı & Toplam & & 13.67 & 36.67 & $\begin{array}{c}23.18 \\
(\mathbf{3 8 . 6 3})^{*}\end{array}$ & 8.48 \\
\hline & Diyafram Nefesini Doğru ve Verimli Kullanabilme & 1 & & 1.00 & 3.50 & 2.07 & .93 \\
\hline & Notaları Doğru Çalabilme & 2 & & 1.00 & 3.17 & 1.80 & .80 \\
\hline & $\begin{array}{c}\text { Kaliteli -güçlü, parlak, hacimli - Ton Elde } \\
\text { Edebilme }\end{array}$ & 3 & & 1.00 & 3.17 & 2.02 & .81 \\
\hline & Entonasyonu Bozmadan Temiz Ses Üretebilme & 4 & & 1.00 & 3.33 & 1.97 & .84 \\
\hline & Artikülasyonları Doğru Bir Şekilde Uygulayabilme & 5 & 10 & 1.00 & 3.17 & 1.73 & .81 \\
\hline & Parmakları Akıcı Bir Şekilde Kullanabilme & 6 & & 1.00 & 3.17 & 1.88 & .78 \\
\hline & Ritim Kalıplarına Uygun Çalabilme & 7 & & 1.00 & 3.00 & 1.82 & .86 \\
\hline & $\begin{array}{c}\text { Doğru Cümlemeler ile Bütünlük İçerisinde } \\
\text { Çalabilme }\end{array}$ & 8 & & 1.00 & 3.33 & 1.73 & .84 \\
\hline & H1z Terimlerini Uygulayabilme & 9 & & 1.00 & 2.83 & 1.75 & .74 \\
\hline & Nüans Terimlerini Uygulayabilme & 10 & & 1.00 & 2.00 & 1.37 & .41 \\
\hline & Doğru Duruş Pozisyonunu Uygulayabilme & 11 & & 1.67 & 3.67 & 2.53 & 67 \\
\hline & Doğru Tutuş Pozisyonunu Uygulayabilme & 12 & & 1.50 & 3.50 & 2.52 & .68 \\
\hline \multirow{13}{*}{ 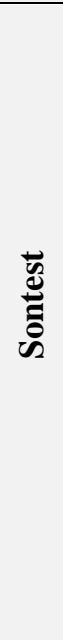 } & Toplam Performans Başarısı & Toplam & & 13.50 & 45.33 & $\begin{array}{c}31.02 \\
(\mathbf{5 1 . 0 7})^{*}\end{array}$ & 10.01 \\
\hline & Diyafram Nefesini Doğru ve Verimli Kullanabilme & 1 & & 1.00 & 4.00 & 2.70 & .93 \\
\hline & Notaları Doğru Çalabilme & 2 & & 1.00 & 4.00 & 2.82 & .91 \\
\hline & $\begin{array}{c}\text { Kaliteli -güçlü, parlak, hacimli-Ton Elde } \\
\text { Edebilme }\end{array}$ & 3 & & 1.00 & 4.00 & 2.70 & .99 \\
\hline & Entonasyonu Bozmadan Temiz Ses Üretebilme & 4 & & 1.00 & 3.50 & 2.55 & .85 \\
\hline & Artikülasyonları Doğru Bir Şekilde Uygulayabilme & 5 & 10 & 1.00 & 4.00 & 2.55 & .98 \\
\hline & Parmakları Akıcı Bir Şekilde Kullanabilme & 6 & & 1.00 & 3.83 & 2.62 & .93 \\
\hline & Ritim Kalıplarına Uygun Çalabilme & 7 & & 1.00 & 4.17 & 2.63 & 1.04 \\
\hline & $\begin{array}{c}\text { Doğru Cümlemeler ile Bütünlük İçerisinde } \\
\text { Çalabilme }\end{array}$ & 8 & & 1.00 & 4.17 & 2.57 & .97 \\
\hline & H1z Terimlerini Uygulayabilme & 9 & & 1.00 & 3.50 & 2.45 & .88 \\
\hline & Nüans Terimlerini Uygulayabilme & 10 & & 1.00 & 2.67 & 1.80 & .59 \\
\hline & Doğru Duruş Pozisyonunu Uygulayabilme & 11 & & 1.83 & 4.00 & 2.83 & .75 \\
\hline & Doğru Tutuş Pozisyonunu Uygulayabilme & 12 & & 1.67 & 3.67 & 2.80 & .69 \\
\hline
\end{tabular}

Tablo 5'teki tanımlayıcı değerler incelendiğinde, deney ve kontrol gurubu olmak üzere çalışma grubunu oluşturan bütün öğrencilerin öntest puanlarının ortalamanın altında olduğu $(\overline{\mathrm{x}}=38.63)$, diğer bir anlatımla performans başarılarının düşük denilebilecek bir düzeyde bulunduğu görülmektedir. Son test puanlarında ise çalışma grubunun başarısının yükselerek ortalama bir seviyede konumlandığı tespit edilmiştir $(\overline{\mathrm{x}}=51.07)$. Alt boyutlar açısından Öntest puanlarına bakıldığında en başarılı olunan alanların; "Doğru Duruş Pozisyonunu Uygulayabilme ( $\overline{\mathrm{x}}=2.53)$ )" ile "Doğru Tutuş Pozisyonunu Uygulayabilme ( $\overline{\mathrm{x}}=2.52)$ "; en düşük başarının gösterildiği alanın ise 
“Nüans Terimlerini Uygulayabilme ( $\overline{\mathrm{x}}=1.37)$ boyutları olduğu görülmektedir. Son test puanları gözlemlendiğinde ise bütün puan türlerinde artış olduğu tespit edilmekle beraber yine aynı alanların yüksek değerler ile dağılımda yer aldıkları, nüans becerilerinin yine düşük bir seyir gösterdiği, "Notaları Doğru Çalabilme ( $\bar{x}=2.82)$ " boyutunun ise en yüksek puan artışının olduğu müziksel davranış boyutu olduğu belirlenmiştir.

Tablo 6' da her öğrencinin performans başarısı boyut puanlarının uygulama öncesi ve sonrası değerleri sunulmuştur.

Tablo 6: Performans Başarısı Boyut Puanlarının Öğrencilere Göre Dağglımı

\begin{tabular}{|c|c|c|c|c|c|c|c|c|c|c|c|c|c|}
\hline & \multicolumn{3}{|c|}{ Diyafram } & \multicolumn{2}{|c|}{ Nota.. D. Ç. } & \multicolumn{2}{|c|}{ Kaliteli Ton } & \multicolumn{2}{|c|}{ Entonasyon } & \multicolumn{2}{|c|}{ Artikülasyon } & \multicolumn{2}{|c|}{ Parmakları K. } \\
\hline & & Ö.test & S.test & Ö.test & S.test & Ö.test & S.test & Ö.test & S.test & Ö.test & S.test & Ö.test & S.test \\
\hline \multirow{5}{*}{ : } & $\ddot{\mathbf{O}}_{1}$ & 3.00 & 3.17 & 2.50 & 3.00 & 3.17 & 3.17 & 3.17 & 3.00 & 3.17 & 3.00 & 2.50 & 2.50 \\
\hline & $\mathbf{O}_{2}$ & 1.50 & 3.17 & 1.17 & 3.50 & 1.83 & 2.83 & 1.67 & 3.17 & 1.00 & 2.50 & 1.33 & 3.00 \\
\hline & $\mathbf{O}_{3}$ & 2.00 & 2.50 & 1.67 & 2.67 & 2.17 & 2.67 & 2.17 & 2.50 & 1.50 & 2.17 & 1.67 & 2.50 \\
\hline & $\ddot{O}_{4}$ & 3.50 & 3.83 & 3.00 & 3.33 & 3.00 & 3.67 & 2.50 & 3.17 & 2.17 & 3.50 & 2.67 & 3.67 \\
\hline & $\ddot{O}_{5}$ & 2.33 & 3.17 & 1.67 & 3.83 & 1.83 & 3.67 & 2.00 & 3.50 & 1.67 & 3.67 & 2.50 & 3.67 \\
\hline \multirow{7}{*}{$\begin{array}{l}\overline{0} \\
\bar{t} \\
\overline{0}\end{array}$} & $\ddot{O}_{6}$ & 3.33 & 4.00 & 3.17 & 4.00 & 3.00 & 4.00 & 3.33 & 3.33 & 3.00 & 4.00 & 3.17 & 3.83 \\
\hline & $\ddot{\mathbf{O}}_{7}$ & 1.17 & 2.17 & 1.00 & 2.33 & 1.17 & 2.50 & 1.17 & 2.17 & 1.17 & 2.17 & 1.17 & 2.17 \\
\hline & $\ddot{O}_{8}$ & 1.67 & 2.00 & 1.33 & 2.50 & 1.83 & 2.17 & 1.67 & 2.33 & 1.67 & 2.00 & 1.83 & 2.17 \\
\hline & O9 & 1.00 & 1.00 & 1.00 & 1.00 & 1.00 & 1.00 & 1.00 & 1.00 & 1.00 & 1.00 & 1.00 & 1.00 \\
\hline & $\ddot{O}_{10}$ & 1.17 & 2.00 & 1.50 & 2.00 & 1.17 & 1.33 & 1.00 & 1.33 & 1.00 & 1.50 & 1.00 & 1.67 \\
\hline & \multicolumn{3}{|c|}{ Ritim K. U. Ç. } & \multicolumn{2}{|c|}{ Cümlemele } & \multicolumn{2}{|c|}{ Hız Terimleri } & \multicolumn{2}{|c|}{ Nüans } & \multicolumn{2}{|c|}{ Duruș } & \multicolumn{2}{|c|}{ Tutuş } \\
\hline & & Ö.test & S.test & Ö.test & S.test & Ö.test & S.test & Ö.test & S.test & Ö.test & S.test & Ö.test & S.test \\
\hline \multirow{5}{*}{ } & $\ddot{O}_{1}$ & 3.00 & 3.33 & 2.67 & 3.00 & 2.50 & 2.50 & 1.67 & 1.67 & 3.67 & 3.50 & 3.50 & 3.33 \\
\hline & $\mathbf{O}_{2}$ & 1.00 & 3.00 & 1.00 & 2.83 & 1.00 & 3.33 & 1.00 & 2.17 & 1.83 & 2.00 & 2.00 & 2.33 \\
\hline & $\mathbf{O}_{3}$ & 1.17 & 2.00 & 1.00 & 2.17 & 2.00 & 2.17 & 1.33 & 1.50 & 1.67 & 2.50 & 1.50 & 2.33 \\
\hline & $\ddot{O}_{4}$ & 3.00 & 3.67 & 2.50 & 3.67 & 2.67 & 3.50 & 2.00 & 2.67 & 2.83 & 3.00 & 3.00 & 3.17 \\
\hline & $\ddot{O}_{5}$ & 1.83 & 3.33 & 1.83 & 3.17 & 2.00 & 3.00 & 1.50 & 2.00 & 2.50 & 3.67 & 2.67 & 3.67 \\
\hline \multirow{5}{*}{$\begin{array}{l}\overline{0} \\
\overline{0} \\
\overline{0}\end{array}$} & $\ddot{O}_{6}$ & 3.00 & 4.17 & 3.33 & 4.17 & 2.83 & 3.50 & 2.00 & 2.67 & 3.33 & 4.00 & 3.17 & 3.67 \\
\hline & $\ddot{\mathbf{O}}_{7}$ & 1.17 & 2.50 & 1.00 & 2.00 & 1.00 & 2.00 & 1.00 & 1.83 & 3.00 & 3.00 & 3.00 & 3.00 \\
\hline & $\ddot{O}_{8}$ & 1.33 & 2.00 & 1.50 & 2.00 & 1.33 & 2.17 & 1.17 & 1.50 & 2.50 & 2.83 & 2.67 & 2.83 \\
\hline & $\mathbf{O}_{9}$ & 1.00 & 1.00 & 1.00 & 1.00 & 1.00 & 1.00 & 1.00 & 1.00 & 2.00 & 1.83 & 1.67 & 1.67 \\
\hline & $\ddot{O}_{10}$ & 1.67 & 1.33 & 1.50 & 1.67 & 1.17 & 1.33 & 1.00 & 1.00 & 2.00 & 2.00 & 2.00 & 2.00 \\
\hline
\end{tabular}

Tablo 6 incelendiğinde, özellikle deney grubu öğrencilerinin birçok boyut puanlarında uygulama sonrasındaki ölçümlerde genel anlamda yükselmeler olduğu görülmektedir. Kontrol grubunda ise deney grubu öğrencilerinden daha düşük değerlere sahip olmakla beraber başarı düzeyi yükselen öğrenciler olduğu gibi performans başarısı düşüş eğilimine geçen öğrencilerin de yer aldığ 1 , uygulama sonrası başarı durumunda heterojen bir görünüm sergileyen bir dağılımın gerçekleştiği söylenebilir.

\section{2. Çalışma Grubunun Performans Başarısı ve Boyut Puanlarına Yönelik Bulgular}

$\mathrm{Bu}$ alt başlıkta, çalışmanın ikinci alt problemine ilişkin bulgular sunulmuştur. Aşamalı kas gevşeme egzersizleri ile geleneksel yaklaşıma göre yapılan flüt öğretimi öncesinde ve sonrasında deney ve kontrol grubundaki öğrencilere yapılan ölçümler arasındaki farklılık düzeyleri ve anlamlılık durumları incelenmiş̧ir. Analiz işlemlerinde toplam performans başarısı puanları ve toplam başarının kapsadığı 12 alt boyut puanları, Gariboldi Etüt ve Moyse Etüt puanları üzerinden ayrı ayrı ayrı değerlendirilmiştir. Buradan hareketle, 12 faktörden oluşan performans başarısı puanlarının deney ve kontrol gruplarının öntest-sontest farklılıkları için Wilcoxon İşaretli Siralar Testi; sontest puanları arasındaki farklılıkların tespit edilmesi amacıyla ise Mann-Whitney $U$ testi değerleri hesaplanmıştır. Etki büyüklüklerinin hesaplanmasında ise $r$ değerleri dikkate alınmıştır. 
Deney ve kontrol gruplarının toplam performans başarısı öntest-sontest puanlarının Wilcoxon İşaretli Sıralar Testi sonuçları Tablo 7'de verilmiştir.

Tablo 7: Deney ve Kontrol Gruplarının Toplam Performans Başarısı Öntest-Sontest Puanlarının Wilcoxon İșaretli Sıralar Testi Sonuçları

\begin{tabular}{|c|c|c|c|c|c|c|c|c|c|}
\hline Puan Türü & $\begin{array}{l}\text { Öntest- } \\
\text { Sontest }\end{array}$ & $\mathbf{N}$ & S. 0. & S. T. & $\bar{X}_{\text {ön }}$ & $\bar{X}_{\text {son }}$ & $\mathbf{z}$ & $\mathbf{p}$ & $\mathbf{r}$ \\
\hline \multirow[b]{2}{*}{$\mathrm{D}_{\ddot{o}}-\mathrm{D}_{\mathrm{s}}$} & Negatif S. & 0 & .00 & .00 & & & & & \\
\hline & $\begin{array}{c}\text { Pozitif S. } \\
\text { Eșit }\end{array}$ & $\begin{array}{l}5 \\
0\end{array}$ & 3.00 & 15.00 & 42.61 & 59.28 & $-2.02^{*}$ & .04 & -.64 \\
\hline \multirow[b]{2}{*}{$\mathrm{K}_{\ddot{0}}-\mathrm{K}_{\mathrm{s}}$} & Negatif S. & 1 & 1.00 & 1.00 & & & & & \\
\hline & $\begin{array}{c}\text { Pozitif S. } \\
\text { Esit }\end{array}$ & $\begin{array}{l}4 \\
0\end{array}$ & 3.50 & 14.00 & 34.66 & 44.11 & -1.75 & .08 & - \\
\hline
\end{tabular}

Tablo 7'deki analiz sonuçlarına bakıldığında, uygulama sonrasında deney grubunun performans başarılarının anlamlı düzeyde yükseldiği açıkça görülmektedir. [z=-2.02, $\mathrm{p}<.05]$. Pozitif sıralar lehine anlamlı bir farklılık olduğu, deney grubunu oluşturan öğrencilerin hepsinin başarısının arttığı saptanmıştır. Buradan hareketle aşamalı kas gevşeme egzersizlerinin flüt performans başarısını olumlu yönde etkilediği söylenebilir. Etki büyüklüğü değerinin ise yüksek düzeyde olduğu belirlenmiştir [r=.64>.50]. Kontrol grubu puanlarındaki farklılıkların ise anlamlı düzeyde olmadığı, 1 öğrencinin performans başarısı puanının düştüğü, 4 öğrencinin ise puanlarının yükseldiği tespit edilmiştir.

Deney ve kontrol gruplarının toplam performans başarısının kapsadığı alt boyutlara ilişkin öntest-sontest puanlarının Wilcoxon İşaretli Sıralar Testi sonuçları; sadece, anlamlı farklılı̆̆ın çıktığı alt boyutlarda sunulmuştur.

Deney ve kontrol gruplarının "Diyafram Nefesini Doğru ve Verimli Kullanabilme" öntestsontest puanlarının Wilcoxon İşaretli Sıralar Testi sonuçları Tablo 8'de verilmiştir.

Tablo 8: Deney ve Kontrol Gruplarının Diyafram Nefesini Doğru ve Verimli Kullanabilme ÖntestSontest Puanlarının Wilcoxon İşaretli Sıralar Testi Sonuçları

\begin{tabular}{|c|c|c|c|c|c|c|c|c|c|}
\hline Puan Türü & $\begin{array}{l}\text { Öntest- } \\
\text { Sontest }\end{array}$ & $\mathbf{N}$ & S. 0. & S. T. & $\bar{X}_{\text {ön }}$ & $\bar{X}_{\text {son }}$ & $\mathbf{z}$ & $\mathbf{p}$ & $\mathbf{r}$ \\
\hline \multirow{3}{*}{$D_{\ddot{0}}-D_{s}$} & Negatif S. & 0 & .00 & .00 & & & & & \\
\hline & Pozitif S. & 5 & 3.00 & 15.00 & 2.47 & 3.17 & $-2.02^{*}$ & .04 & -.64 \\
\hline & Eşit & 0 & & & & & & & \\
\hline \multirow{3}{*}{$\mathrm{K}_{\ddot{o}}-\mathrm{K}_{\mathrm{s}}$} & Negatif S. & 0 & .00 & .00 & & & & & \\
\hline & Pozitif S. & 4 & 2.50 & 10.00 & 1.67 & 2.23 & -1.83 & .07 & - \\
\hline & Eşit & 1 & & & & & & & \\
\hline
\end{tabular}

Tablo 8'deki Wilcoxon İşaretli Sıralar testi analiz sonuçlarında görüldüğü üzere farklılığın pozitif sıralar lehine olduğu, aşamalı kas gevşeme egzersizi etkinliklerinden sonra deney grubunda yer alan 5 öğrencinin tümünün "Diyafram Nefesini Doğru ve Verimli Kullanabilme" becerilerinin anlamlı düzeyde arttığı tespit edilmiştir. $[\mathrm{z}=-2.02, \mathrm{p}<.05]$. Etki büyüklüğü değerinin ise yüksek düzeyde olduğu saptanmıştır $[\mathrm{r}=.64>.50]$. Kontrol grubu öğrencilerinin dördünün sıralamasının uygulama öncesine göre pozitif bir yönde olduğu, bir öğrencinin başarı durumunun değişmediği, ortaya çıkan pozitif farklılıkların ise anlamlı düzeyde olmadığı saptanmıştır. 
Tablo 9'da deney ve kontrol gruplarının “Notaları Doğru Çalabilme” öntest-sontest puanlarının Wilcoxon İşaretli Sıralar Testi sonuçları aşağıda verilmiştir.

Tablo 9: Deney ve Kontrol Gruplarının Notaları Doğru Çalabilme Öntest-Sontest Puanlarının Wilcoxon İşaretli Sıralar Testi Sonuçları

\begin{tabular}{|c|c|c|c|c|c|c|c|c|c|}
\hline Puan Türü & $\begin{array}{l}\text { Öntest- } \\
\text { Sontest }\end{array}$ & $\mathbf{N}$ & S. 0. & S. T. & $\bar{X}_{\text {ön }}$ & $\bar{X}_{\text {son }}$ & $\mathbf{z}$ & p & $\mathbf{r}$ \\
\hline & Negatif S. & 0 & .00 & .00 & & & & & \\
\hline $\mathrm{D}_{\mathrm{o}}-\mathrm{D}_{\mathrm{s}}$ & $\begin{array}{c}\text { Pozitif S. } \\
\text { Eşit }\end{array}$ & $\begin{array}{l}5 \\
0\end{array}$ & 3.00 & 15.00 & 2.00 & 3.27 & $-2.02^{*}$ & .04 & -.64 \\
\hline & Negatif S. & 0 & .00 & .00 & & & & & \\
\hline $\mathrm{K}_{\ddot{o}}-\mathrm{K}_{\mathrm{s}}$ & $\begin{array}{c}\text { Pozitif S. } \\
\text { Eşit }\end{array}$ & $\begin{array}{l}4 \\
1\end{array}$ & 2.50 & 10.00 & 1.60 & 2.37 & -1.83 & .07 & - \\
\hline
\end{tabular}

Tablo 9'daki analiz sonuçlarına göre, deney grubunun uygulama öncesi ve sonras1 puanlarında deney grubu lehine anlamlı düzeyde farkl11ık olduğu, bütün öğrencilerin flüt performansı kapsamında notaları daha doğru çaldıkları tespit edilmiştir $[\mathrm{z}=-2.02, \mathrm{p}<.05]$. Farklılıkların pozitif sıralar lehine olması, aşamalı kas gevşeme egzersizleri programının, "Notaları Doğru Çalabilme" üzerindeki etkililiğini ortaya koymaktadır. Etki büyüklügünün yüksek olduğu belirlenmiştir [r= .64>.50]. Kontrol grubu öğrencilerin dördünün puanlarının yükseldiği fakat bu farklılıkların anlamlı düzeyde olmadığı, birinin ise uygulama sonrasında başarı durumunda değişiklik olmadığı görülmektedir.

Deney ve kontrol gruplarının "Ritim Kalıplarına Uygun Çalabilme" öntest-sontest puanlarının Wilcoxon İşaretli Sıralar Testi sonuçları Tablo 10’ da sunulmuştur.

Tablo10: Deney ve kontrol gruplarının "Ritim Kalıplarına Uygun Çalabilme” öntestsontest puanlarının Wilcoxon İşaretli Sıralar Testi sonuçları

\begin{tabular}{|c|c|c|c|c|c|c|c|c|c|}
\hline Puan Türü & $\begin{array}{l}\text { Öntest- } \\
\text { Sontest }\end{array}$ & $\mathbf{N}$ & S. O. & S. T. & $\bar{X}_{\text {ön }}$ & $\overline{\mathrm{X}}_{\text {son }}$ & $\mathbf{z}$ & $\mathbf{p}$ & $\mathbf{r}$ \\
\hline \multirow[b]{2}{*}{$\mathrm{D}_{\mathrm{o}}-\mathrm{D}_{\mathrm{s}}$} & Negatif S. & 0 & .00 & .00 & & & & & \\
\hline & $\begin{array}{c}\text { Pozitif S. } \\
\text { Esit }\end{array}$ & $\begin{array}{l}5 \\
0\end{array}$ & 3.00 & 15.00 & 2.00 & 3.07 & $-2.02^{*}$ & .04 & -.64 \\
\hline \multirow[b]{2}{*}{$\mathrm{K}_{\mathrm{o}}-\mathrm{K}_{\mathrm{s}}$} & Negatif S. & 1 & 1.00 & 1.00 & & & & & \\
\hline & $\begin{array}{c}\text { Pozitif S. } \\
\text { Essit }\end{array}$ & $\begin{array}{l}3 \\
1\end{array}$ & 3.00 & 9.00 & 1.63 & 2.20 & -1.46 & .14 & - \\
\hline
\end{tabular}

Tablo 10'daki analiz sonuçlarına bakıldığında, uygulama sonrasında deney grubu öğrencilerinin hepsinin "Ritim Kalıplarına Uygun Çalabilme" puanlarının yükseldiği, ortaya çıkan bu farklılıkların ise anlamlı düzeyde olduğu görülmüştür $[\mathrm{z}=-2.02, \mathrm{p}<.05]$. Etki büyüklüğu düzeyinin ise yüksek olduğu belirlenmiştir [r=.64>.50]. Kontrol grubunda ise bir öğrencinin bu boyuta ilişkin becerilerinde gerileme olduğu, bir öğrencinin aynı düzeyde kaldığı, üç öğrencinin ise becerilerinde gelişim olduğu görülmekle beraber farklılıkların anlamlı düzeyde olmadığı tespit edilmiştir.

Tablo 11'de deney ve kontrol gruplarının "Doğru Cümlemeler ile Bütünlük İçerisinde Çalabilme" öntest-sontest puanlarının Wilcoxon İşaretli Sıralar Testi sonuçları verilmiştir. 
Tablo 11: Deney ve kontrol gruplarının "Doğru Cümlemeler ile Bütünlük İçerisinde Çalabilme" öntest-sontest puanlarının Wilcoxon İşaretli Sıralar Testi sonuçları

\begin{tabular}{|c|c|c|c|c|c|c|c|c|c|}
\hline Puan Türü & $\begin{array}{l}\text { Öntest- } \\
\text { Sontest }\end{array}$ & $\mathbf{N}$ & S. 0. & S. T. & $\bar{X}_{\text {ön }}$ & $\overline{\mathrm{X}}_{\text {son }}$ & $\mathbf{z}$ & $\mathbf{p}$ & $\mathbf{r}$ \\
\hline & Negatif S. & 0 & .00 & .00 & & & & & \\
\hline$D_{\ddot{o}}-D_{s}$ & $\begin{array}{c}\text { Pozitif S. } \\
\text { Eşit }\end{array}$ & $\begin{array}{l}5 \\
0\end{array}$ & 3.00 & 15.00 & 1.80 & 2.97 & $-2.03^{*}$ & .04 & -.64 \\
\hline & Negatif S. & 0 & .00 & .00 & & & & & \\
\hline $\mathrm{K}_{\ddot{o}}-\mathrm{K}_{\mathrm{s}}$ & $\begin{array}{c}\text { Pozitif S. } \\
\text { Essit }\end{array}$ & $\begin{array}{l}4 \\
1\end{array}$ & 2.50 & 10.00 & 1.63 & 2.03 & -1.83 & .07 & - \\
\hline
\end{tabular}

Tablo 11'deki analiz sonuçlarına göre deney grubunun uygulama öncesi ve sonrası "Doğru Cümlemeler ile Bütünlük IÇerisinde Çalabilme" puanlarında anlamlı farklılık olduğu tespit edilmiştir $[\mathrm{z}=-2.03, \mathrm{p}<.05]$. Etki büyüklüğü düzeyinin ise yüksek olduğu görülmüştür [r=.64>.50]. Kontrol grubunda bir öğrencinin bu boyuttaki becerilerinin aynı düzeyde kaldığı, geri kalan dört öğrencinin becerilerinin arttığı fakat farklılıkların anlamlı düzeyde olmadığ 1 gözlemlenmiştir.

Deney ve kontrol gruplarının Gariboldi (Etüt-1) ve Moyse (Etüt-2) öntest-sontest puanlarının Wilcoxon İşaretli Sıralar Testi sonuçları Tablo 12'de sunulmuştur.

Tablo 12: Deney ve Kontrol Gruplarının Gariboldi ve Moyse Etütlerine Yönelik Öntest-Sontest Toplam Puanlarının Wilcoxon İşaretli Sıralar Testi Sonuçları

\begin{tabular}{|c|c|c|c|c|c|c|c|c|c|c|}
\hline & Puan Türü & $\begin{array}{l}\text { Öntest- } \\
\text { Sontest }\end{array}$ & $\mathbf{N}$ & S. O. & S. T. & $\bar{X}_{\text {ön }}$ & $\bar{X}_{\text {son }}$ & $\mathbf{z}$ & $\mathbf{p}$ & $\mathbf{r}$ \\
\hline \multirow{4}{*}{ 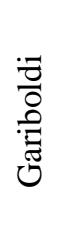 } & & Negatif S. & 1 & 1.00 & 1.50 & & & & & \\
\hline & $D_{00}-D_{s}$ & $\begin{array}{c}\text { Pozitif S. } \\
\text { Eşit }\end{array}$ & $\begin{array}{l}4 \\
0\end{array}$ & 3.50 & 14.00 & 47.00 & 62.45 & -1.75 & .08 & - \\
\hline & & Negatif S. & 0 & .00 & .00 & & & & & \\
\hline & $\mathrm{K}_{\ddot{o}}-\mathrm{K}_{\mathrm{s}}$ & $\begin{array}{l}\text { Pozitif S. } \\
\text { Eşit }\end{array}$ & $\begin{array}{l}4 \\
1\end{array}$ & 2.50 & 10.00 & 36.22 & 47.11 & -1.83 & .07 & - \\
\hline \multirow{4}{*}{ 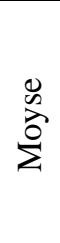 } & & Negatif S. & 0 & .00 & .00 & & & & & \\
\hline & $\mathrm{D}_{\ddot{\mathrm{o}}}-\mathrm{D}_{\mathrm{s}}$ & $\begin{array}{c}\text { Pozitif S. } \\
\text { Eşit }\end{array}$ & $\begin{array}{l}5 \\
0\end{array}$ & 3.00 & 15.00 & 38.22 & 56.11 & $-2.03^{*}$ & .04 & -.64 \\
\hline & & Negatif S. & 2 & 1.50 & 3.00 & & & & & \\
\hline & $\mathrm{K}_{\tilde{o}}-\mathrm{K}_{\mathrm{s}}$ & $\begin{array}{c}\text { Pozitif S. } \\
\text { Eşit }\end{array}$ & $\begin{array}{l}3 \\
0\end{array}$ & 4.00 & 12.00 & 33.11 & 41.11 & -1.83 & .07 & - \\
\hline
\end{tabular}

*p<.05

Tablo 12'deki uygulama öncesi ve sonrası etütlere yönelik performans başarısı puanlarına ilişkin analiz sonuçlarına göre sadece deney grubunun Moyse (Etüt-2) puanlarında pozitif sıralar lehine anlamlı düzeyde farklılık olduğu tespit edilmiştir $[\mathrm{z}=-2.03, \mathrm{p}<.05]$. Etki büyüklügünün ise yüksek seviyede olduğu görülmüştür [r=.64>.50]. Buradan hareketle aşamalı kas gevşeme egzersizlerine dayalı programın anlamlı düzeyde etkililiğinin, Moyse Etüt icrasındaki başarıda gözlemlendiği söylenebilir. Diğer puan türlerinde; gelişim, düşüş ve eşitlik gösteren veriler yer almasına karşın bu farklılıkların anlamlı düzeyde olmadığı saptanmıştır.

Tablo 13'te deney ve kontrol gruplarının performans başarısı boyutlarına göre Moyse (Etüt2) öntest-sontest puanlarının Wilcoxon İşaretli Sıralar Testi sonuçları verilmiştir. 
Tablo 13: Deney ve Kontrol Grubunun Performans Başarısının Boyutlarına Göre Moyse Etüt Öntest-Sontest Puanlarının Wilcoxon İşaretli Sıralar Testi Sonuçları

\begin{tabular}{|c|c|c|c|c|c|c|c|c|c|c|}
\hline & Puan Türü & $\begin{array}{l}\text { Öntest- } \\
\text { Sontest }\end{array}$ & $\mathbf{N}$ & S. 0. & S. T. & $\bar{X}_{\text {ön }}$ & $\begin{array}{c}\bar{X}_{\text {so }} \\
n\end{array}$ & $\mathbf{z}$ & $\mathbf{p}$ & $\mathbf{r}$ \\
\hline \multirow{2}{*}{$\begin{array}{l}\text { Diyafram } \\
\text { Nefesini Doğru } \\
\text { ve Verimli } \\
\text { Kullanabilme }\end{array}$} & $D_{\ddot{o}}-D_{s}$ & $\begin{array}{l}\text { Negatif S. } \\
\text { Pozitif S. } \\
\text { Eşit }\end{array}$ & $\begin{array}{l}0 \\
5 \\
0\end{array}$ & $\begin{array}{c}.00 \\
3.00\end{array}$ & $\begin{array}{c}.00 \\
15.00\end{array}$ & $\begin{array}{c}2.4 \\
0\end{array}$ & 3.13 & $-2.04^{*}$ & $\begin{array}{l}.0 \\
4\end{array}$ & .65 \\
\hline & $\mathrm{K}_{\ddot{0}}-\mathrm{K}_{\mathrm{s}}$ & $\begin{array}{l}\text { Negatif S. } \\
\text { Pozitif S. } \\
\text { Eşit }\end{array}$ & $\begin{array}{l}0 \\
3 \\
2\end{array}$ & $\begin{array}{l}.00 \\
2.00\end{array}$ & $\begin{array}{l}.00 \\
6.00\end{array}$ & $\begin{array}{c}1.6 \\
0\end{array}$ & 2.00 & -1.73 & $\begin{array}{l}.0 \\
8\end{array}$ & - \\
\hline \multirow{2}{*}{$\begin{array}{l}\text { Notaları Doğru } \\
\text { Çalabilme }\end{array}$} & $\mathrm{D}_{\ddot{\mathrm{o}}}-\mathrm{D}_{\mathrm{s}}$ & $\begin{array}{c}\text { Negatif S. } \\
\text { Pozitif S. } \\
\text { Eşit }\end{array}$ & $\begin{array}{l}0 \\
5 \\
0\end{array}$ & $\begin{array}{l}.00 \\
3.00\end{array}$ & $\begin{array}{c}.00 \\
15.00\end{array}$ & $\begin{array}{c}1.5 \\
3\end{array}$ & 2.93 & $-2.04^{*}$ & $\begin{array}{l}.0 \\
4\end{array}$ & .65 \\
\hline & $\mathrm{K}_{\ddot{0}}-\mathrm{K}_{\mathrm{s}}$ & $\begin{array}{c}\text { Negatif S. } \\
\text { Pozitif } S . \\
\text { Eşit }\end{array}$ & $\begin{array}{l}1 \\
3 \\
1\end{array}$ & $\begin{array}{l}1.00 \\
3.00\end{array}$ & $\begin{array}{l}1.00 \\
9.00\end{array}$ & $\begin{array}{c}1.4 \\
7\end{array}$ & 2.07 & -1.47 & $\begin{array}{l}.1 \\
4\end{array}$ & - \\
\hline \multirow[b]{2}{*}{$\begin{array}{l}\text { Kaliteli -güçlü, } \\
\text { parlak, hacimli } \\
\text { - Ton Elde } \\
\text { Edebilme }\end{array}$} & $\mathrm{D}_{\ddot{0}}-\mathrm{D}_{\mathrm{s}}$ & $\begin{array}{c}\text { Negatif S. } \\
\text { Pozitif S. } \\
\text { Eşit }\end{array}$ & $\begin{array}{l}0 \\
5 \\
0 \\
\end{array}$ & $\begin{array}{l}.00 \\
3.00\end{array}$ & $\begin{array}{c}.00 \\
15.00\end{array}$ & $\begin{array}{c}2.2 \\
7\end{array}$ & 3.13 & $-2.03^{*}$ & $\begin{array}{l}.0 \\
4\end{array}$ & .64 \\
\hline & $\mathrm{K}_{\ddot{o}}-\mathrm{K}_{\mathrm{s}}$ & $\begin{array}{c}\text { Negatif S. } \\
\text { Pozitif S. } \\
\text { Eşit } \\
\text { Pozitif S. } \\
\text { Eşit } \\
\end{array}$ & $\begin{array}{l}0 \\
3 \\
2 \\
2 \\
3 \\
\end{array}$ & $\begin{array}{l}.00 \\
2.00\end{array}$ & $\begin{array}{l}.00 \\
6.00\end{array}$ & $\begin{array}{c}1.5 \\
3\end{array}$ & 2.00 & -1.63 & $\begin{array}{l}.1 \\
0\end{array}$ & - \\
\hline \multirow{2}{*}{$\begin{array}{l}\text { Artikülasyonlar } \\
\text { I Doğru Bir } \\
\text { Şekilde } \\
\text { Uygulayabilme }\end{array}$} & $\mathrm{D}_{\ddot{\mathrm{o}}}-\mathrm{D}_{\mathrm{s}}$ & $\begin{array}{c}\text { Negatif S. } \\
\text { Pozitif S. } \\
\text { Eşit }\end{array}$ & $\begin{array}{l}0 \\
5 \\
0 \\
\end{array}$ & $\begin{array}{l}.00 \\
3.00\end{array}$ & $\begin{array}{c}.00 \\
15.00\end{array}$ & $\begin{array}{c}1.6 \\
7\end{array}$ & 2.93 & $-2.03^{*}$ & $\begin{array}{l}.0 \\
4\end{array}$ & .64 \\
\hline & $\mathrm{K}_{\ddot{0}}-\mathrm{K}_{\mathrm{s}}$ & $\begin{array}{c}\text { Negatif S. } \\
\text { Pozitif S. } \\
\text { Eşit }\end{array}$ & $\begin{array}{l}0 \\
4 \\
1 \\
\end{array}$ & $\begin{array}{l}.00 \\
2.50\end{array}$ & $\begin{array}{l}.00 \\
10.00\end{array}$ & $\begin{array}{c}1.5 \\
3\end{array}$ & 2.00 & -1.84 & $\begin{array}{l}.0 \\
7\end{array}$ & - \\
\hline \multirow{2}{*}{$\begin{array}{c}\text { Parmakları } \\
\text { Akıcı Bir } \\
\text { Şekilde } \\
\text { Kullanabilme }\end{array}$} & $\mathrm{D}_{\ddot{o}}-\mathrm{D}_{\mathrm{s}}$ & $\begin{array}{c}\text { Negatif S. } \\
\text { Pozitif S. } \\
\text { Eşit }\end{array}$ & $\begin{array}{l}0 \\
5 \\
0 \\
\end{array}$ & $\begin{array}{c}.00 \\
3.00\end{array}$ & $\begin{array}{c}.00 \\
15.00\end{array}$ & $\begin{array}{c}1.7 \\
3\end{array}$ & 2.87 & $-2.03 *$ & $\begin{array}{l}.0 \\
4\end{array}$ & .64 \\
\hline & $\mathrm{K}_{\ddot{0}}-\mathrm{K}_{\mathrm{s}}$ & $\begin{array}{c}\text { Negatif S. } \\
\text { Pozitif S. } \\
\text { Eşit } \\
\text { Pozitif S. } \\
\text { Eşit } \\
\end{array}$ & $\begin{array}{l}0 \\
4 \\
1 \\
3 \\
1\end{array}$ & $\begin{array}{l}.00 \\
2.50\end{array}$ & $\begin{array}{l}.00 \\
10.00\end{array}$ & $\begin{array}{c}1.5 \\
3\end{array}$ & 1.93 & -1.86 & $\begin{array}{l}.0 \\
6\end{array}$ & - \\
\hline \multirow{2}{*}{$\begin{array}{c}\text { Doğru } \\
\text { Cümlemeler ile } \\
\text { Bütünlük } \\
\text { İçerisinde } \\
\text { Çalabilme }\end{array}$} & $\mathrm{D}_{\ddot{0}}-\mathrm{D}_{\mathrm{s}}$ & $\begin{array}{c}\text { Negatif S. } \\
\text { Pozitif S. } \\
\text { Eşit }\end{array}$ & $\begin{array}{l}0 \\
5 \\
0 \\
\end{array}$ & $\begin{array}{l}.00 \\
3.00\end{array}$ & $\begin{array}{c}.00 \\
15.00\end{array}$ & $\begin{array}{c}1.5 \\
3\end{array}$ & 2.60 & $-2.066^{*}$ & $\begin{array}{l}.0 \\
3\end{array}$ & .65 \\
\hline & $\mathrm{K}_{\ddot{0}}-\mathrm{K}_{\mathrm{s}}$ & $\begin{array}{c}\text { Negatif S. } \\
\text { Pozitif S. } \\
\text { Eşit } \\
\text { Pozitif S. } \\
\text { Eşit } \\
\end{array}$ & $\begin{array}{l}1 \\
3 \\
1 \\
3 \\
1 \\
\end{array}$ & $\begin{array}{l}1.00 \\
3.00\end{array}$ & $\begin{array}{l}1.00 \\
9.00\end{array}$ & $\begin{array}{c}1.6 \\
0\end{array}$ & 2.07 & -1.47 & $\begin{array}{l}.1 \\
4\end{array}$ & - \\
\hline
\end{tabular}

Tablo 13'teki Moyse öntest-sontest puanlarına ilişkin analiz sonuçları incelendiğinde; "Diyafram Nefesini Doğru ve Verimli Kullanabilme", "Notaları Doğru Çalabilme”, "Kaliteli güçlü, parlak, hacimli - Ton Elde Edebilme", "Artikülasyonları Doğru Bir Şekilde Uygulayabilme”, "Parmakları Akıcı Bir Şekilde Kullanabilme", "Doğru Cümlemeler ile Bütünlük İçerisinde 
Çalabilme" boyutlarında anlamlı düzeyde, pozitif sıralar lehine anlamlı farklılıklar olduğu tespit edilmiştir. Etki büyüklükleri düzeylerine bakıldığında ise anlamlılık gösteren bütün kategorilerdeki değerlerin yüksek düzeyde oldukları görülmüştür [r>.50]. Bu boyutlar dışındaki diğer (duruş, tutuş pozisyonu, hız ve nüans terimleri vd.) alt faktör puanlarında ise anlamlı farklılıklar çıkmadığı tespit edilmiştir [p>.05].

Tablo 14'te deney ile kontrol gruplarının toplam performans başarısı sontest puanlarındaki ortalama farklı1ıklarına ilişkin Mann-Whitney U testi sonuçları yer almaktadır.

Tablo 14: Deney ve Kontrol Gruplarının Toplam Performans Başarısı Sontest Puanlarının MannWhitney U Testi Sonuçları

\begin{tabular}{cccccccccc}
\hline Puan Türü & Grup & $\mathbf{N}$ & S.O. & S. T. & $\overline{\mathbf{X}}_{\text {son }}$ & $\mathbf{U}$ & $\mathbf{z}$ & $\mathbf{p}$ & r \\
\hline Toplam Performans & Deney & 5 & 6.80 & 34.00 & 59.28 & \multirow{2}{*}{21.00} & -.18 & .18 & - \\
Başarıs1 Sontest & Kontrol & 5 & 4.20 & 21.00 & 44.11 & & & & \\
\hline
\end{tabular}

Tablo 14'te görüldüğü üzere, deney grubunun sontest puanlarının, kontrol grubunun sontest puanlarından yüksek olduğu görülmekle beraber sıra ortalamaları ve toplamları dikkate alındığında grupların sontest puanlarındaki farklılığın anlamlı düzeyde olmadığı görülmüştür. Ayrıca, performans başarısını oluşturan her boyut için ayrı ayrı sontest puanlarındaki değişim incelenmiş ve deney grubu puanlarının tüm alt boyutlar açısından daha yüksek olmasına karşın farklılı̆̆ın anlamlı düzeyde olmadığı tespit edilmiştir.

\section{Sonuç, Tartışma ve Öneriler}

Çalışma grubunun performans başarısı ve boyut puanlarının tanımlayıcı değerlerine ilişkin yapılan ölçümlerde; AKGE uygulamaları öncesinde, çalışma grubunu oluşturan bütün öğrencilerin performans başarılarının düşük denebilecek düzeyde olduğu; AKGE uygulamaları sonrasında ise, bütün öğrencilerin performans başarılarının artarak ortalama bir seviyeye ulaştığı tespit edilmiştir. Performans başarısını oluşturan boyut puanlarının tanımlayıcı değerlerine ilişkin sonuçlara göre ise; uygulama öncesi yapılan ölçümlerde en başarılı olunan teknik becerilerin duruş ve tutuş pozisyonunu doğru bir şekilde uygulayabilme becerisi olduğu; uygulama sonrasında yapılan ölçümlerde ise başarının tüm teknik ve müzikal beceriler açısından artmış olduğu tespit edilmiştir.

Uygulama öncesi ve sonrası yapılan ölçümlere ilişkin sonuçlar karşılaştırıldığında; aşamalı kas gevşeme egzersizlerine dayalı flüt öğretiminin, deney grubu öğrencilerinin performans başarılarını anlamlı bir biçimde yüksek düzeyde ve olumlu yönde arttırdığı sonucuna ulaşılmıştır. Geleneksel flüt öğretiminin uygulandığı kontrol grubu öğrencilerinin puanlarında ise anlamlı bir farklılığın oluşmadığı tespit edilmiştir. Aşamalı kas gevşeme egzersizlerinin uygulandığı bir çok çalışmanın sonucunda, bu araştırma sonucu ile paralel olarak müzisyenlerin performans başarılarının yükseldiği belirlenmiştir (Appel, 1974; Deen, 1999; Kim, 2003). Bu sonucu destekler nitelikte başka bir çalışmada ise, müzik eğitimi alan öğrencilere uygulanan 3 seans çözüm odaklı kısa terapi uygulamaları sonrasında öğrencilerin performans kalitelerinde artış olduğu tespit edilmiştir (BienAime, 2011). Diğer yandan, Rothlisberger' in (1992) kaygı ile başa çıkma yöntemlerinden video modelleme hazırlığını temel alarak yaptığı çalışmasında ise, öğrencilerin çalgı başarıları üzerinde video modelleme hazırlığının anlamlı bir etkisinin olmadığı sonucu ortaya çıkmıştır. Benzer sonuçlar, Mansberger'in (1988) performans kaygısı yönetimi eğitiminin müzikal performans başarısı üzerinde etkisini araştırdığı çalışmasında da karşımıza çıkmaktadır.

Deney grubunun genel performans başarısını oluşturan teknik ve müzikal beceriler $(\mathrm{N}=12)$ açısından bakıldığında "Diyafram Nefesini Doğru ve Verimli Kullanabilme", "Notaları Doğru Çalabilme", "Ritim Kalıplarına Uygun Çalabilme", "Doğru Cümlelemeler ile Bütünlük İçerisinde Çalabilme" boyutlarında ( $\mathrm{N}=4)$ anlamlı ve yüksek düzeyde artış olduğu tespit edilmiş̧tir. Aşamalı kas gevşeme egzersizlerinin; nefes tekniğini doğru bir şekilde kullanarak kasların gevşetilmesi 
temeline dayalı bir rahatlama yöntemi olmasından dolayı diyafram nefesini doğru ve verimli kullanabilme becerisini geliştirdiği; zihni dinlendirdiği, odaklanmayı arttırdığı ve hata yapma oranını düşürdüğü için notaları, ritim kalıplarını, cümlelemeleri doğru bir şekilde ve akıcılığı bozmadan çalabilme becerilerini geliştirdiği söylenebilir. Lorenz'in (2002), koro öğrencilerine uyguladığ 1 Alexander Tekniğine dayalı algısal farkındalık ve beden uyumu egzesizlerine dayalı yaptığı çalışmanın sonucunda; yapılan uygulamanın bazı öğrencilerin postürlerini, nefes kontrollerini ve ses tekniğini olumlu yönde etkilediği ortaya çıkmıştır. Uygulanan bu yöntemde olduğu gibi aşamalı kas gevşeme egzersizlerinin de nefes ve beden odaklı çalışmalara dayanması bakımından, bedensel rahatlamayı temel alan egzersizlerin, çalgı eğiminde ve ses eğitiminde performansa ilişkin teknik ve müzikal birçok becerinin gelişmesinde oldukça etkili bir yöntem olduğu söylenebilir.

Performans başarısı üzerinde etkisinin araştırıldığı Gariboldi (Etüt-1) ve Moyse (Etüt-2) etütlere yönelik öntest-sontest puanlarının analiz sonucuna göre; Gariboldi (Etüt-1)'ye göre teknik açıdan daha zengin olan Moyse (Etüt-2) puanlarının; deney grubunun başarısına, anlamlı ve yüksek düzeyde etki ettiği belirlenmiştir. Moyse etütü bağlamında, performans başarısındaki anlamlı yükselişin hangi boyut puanlarında oluştuğuna bakıldığında ise; "Diyafram Nefesini Doğru ve Verimli Kullanabilme", "Notaları Doğru Çalabilme", "Kaliteli -güçlü, parlak, hacimli - Ton Elde Edebilme", "Artikülasyonları Doğru Bir Şekilde Uygulayabilme”, "Parmakları Akıcı Bir Şekilde Kullanabilme", "Doğru Cümlemeler ile Bütünlük İçerisinde Çalabilme" boyutlarında ( $\mathrm{N}=6)$ olduğu tespit edilmiştir. Moyse etütünün Gariboldi etütüne göre hız terimleri, tonalite açısından seviye olarak daha ileri; ritmik yapıdaki ve artikülasyonlardaki çeşitlilik açısından ise daha zengin olmasına rağmen başarı bağlamında daha belirleyici olması AKGE'nin etkisinin yüksek düzeyde olduğunu ortaya koymaktadır. Ayrıca bu tekniklerin yanı sıra aşamalı kas gevşeme egzersizlerinin; rahatlatıcı nefes egzersizlerine dayanması bakımından nefes tekniğini kayda değer bir biçimde geliştirerek ton kalitesini yükseltmiş olduğu; kaslardaki gerilimi azaltması bakımından ise performans sırasındaki kaygı durumunu azaltarak parmakları akıcı bir şekilde kullanabilme, notaları doğru çalabilme ve cümlelemeleri bütünlük içerisinde çalabilme becerilerine olumlu etki etmiş olduğu söylenebilir.

Uygulama sonrası yapılan ölçümlere ilişkin sonuçlar karşılaştırıldığında ise; deney gurubu puanlarının, kontrol grubu puanlarına göre daha yüksek olduğu görülmekle beraber bu farklılığın anlamlı düzeyde olmadığı tespit edilmiştir; fakat sıra ve aritmetik ortalamalara ilişkin puanlar karşılaştırıldığında deney grubunun son test puanlarının daha yüksek olduğu açıkça görülmektedir.

Araştırmanın sonuçları 1şığında şu önerilerde bulunulmaktadır.

Türkiye'de çalgı eğitiminde performans başarısı ile ilgili araştırmalar incelendiğinde, aşamalı kas gevşeme egzersizleri üzerine yapılan herhangi bir çalışmaya rastlanmamıştır. Bu yüzden müzik ve çalg1 eğitimcilerine 1şık tutması ve literatüre katk1 sağlaması açısından diğer çalg1 ve performans alanlarında da AKGE ile ilgili çalışmalar yapılması önerilmektedir.

Dil, parmak ve nefes senkronizasyonu gerektiren flüt eğitiminde öğrenciler, bu koordinasyonunu sağlarken zorlanabilmekte ve farkında olmadan kaslarını aşırı bir biçimde kasma eğilimi gösterebilmektedirler. Bu açıdan, psikoloji literatüründe önemli bir yeri olan bilişseldavranışçı terapiye dayalı aşamalı kas gevşeme egzersizlerinin olumlu etkisinin, flüt performans başarısı üzerine yapılan bu araştırma ile de desteklendiği düşünüldüğünde; bireysel çalg1 (flüt) eğitimi derslerinde, flüt eğitimcilerinin diyafram çalışmalarına başlamadan önce bu egzersizleri uygulamaları önerilmektedir.

Aşamalı kas gevşeme egzersizlerine dayalı çalışmaların, bireysel çalgı eğitimi ve ses eğitimi derslerinin yanı sıra diğer müziksel performans gerektiren alanlarda yapılması önerilmektedir.

Mesleki müzik eğitimi alan öğrencilerin performans başarılarını olumsuz etkileyebilecek düzeyde kaygı yaşamalarının, performans kalitelerine olumsuz etki ettiği bilinmektedir. Öğrencilerin 
bu kaygı durumu ile başa çıkabilmelerine yardımcı olmayı hedefleyen bir dersin müfredata konulması önerilmektedir.

Genelde, müzik eğitimcilerinin; özelde ise çalg1 eğitimcilerinin aşamalı kas gevşeme egzersizleri ile ilgili uygulamaya yönelik eğitimlere katılmaları ve bu eğitimi derslerinde uygulamaları önerilmektedir.

\section{Kaynakça}

Ak, B. (2008). Verilerin düzenlenmesi ve gösterimi. Kalayc1, Ş. (Editör). SPSS uygulamalı çok değişkenli istatistik teknikleri içinde (ss.3-47). Ankara: Asil Yayın Dağıtım.

Appel, S. S. (1974). Modifying solo performance anxiety in adult pianists. Doctoral Dissertation, Columbia University, A.B.D.

BienAime, K. J. (2011). Managing Performance Anxiety In Music Students: Using A Solution Focused Approach. Doctoral Dissertation, Nova Southeastern University.

Bilici, B. (2014). Bireysel çalgı flüt dersi alan öğrencilerin akciğer kapasiteleri ile flüt çalma becerileri arasındaki ilişkinin incelenmesi. Yayımlanmamış Yüksek Lisans Tezi, Gazi Üniversitesi Eğitim Bilimleri Enstitüsü, Ankara

Brotons, M. (1993). Effects of performing conditions on music performance anxiety and performance quality, Doctoral Dissertation, Oregon University.

Büyüköztürk, Ş. (2008). Veri analizi el kitabı: İstatistik, araştırma deseni, SPSS uygulamaları ve yorum. Anakara: Pegem Akademi Yayınları.

Büyüköztürk, Ş., Akgün, Ö. E., Demirel, F., Karadeniz, Ş., \& Çakmak, E. K. (2016). Bilimsel Araştırma Yöntemleri. Ankara: Pegem Akademi Yayınları.

Can, A. (2016). SPSS ile Bilimsel Araştırma Sürecinde Veri Analizi. Ankara: Pegem Akademi.

Deen. R. D. (1999). Awareness And Breathing: Keys To The Moderation Of Musical Performance Anxiety Dissertation. Doctoral Dissertation, Kentucky University.

Dural, T. (2007). Yan flüt eğitiminde diyafram nefesinin önemi ve diyafram nefesinin türkiye'de müzik ögretmeni yetiştiren kurumlardaki yan flüt dersi ögretim programlarındaki yeri. Yayımlanmamış Yüksek Lisans Tezi, Gazi Üniversitesi Eğitim Bilimleri Enstitüsü, Ankara.

Field, A. (2009). Discovering Statistics Using SPSS. London: SAGE Publications.

Fraenkel, J. R., Wallen, N. E., \& Hyun, H. H. (2011). How to design and evaluate research in education. New York: McGraw-Hill Humanities/Social Sciences/Languages.

Fritz, C. O., Morris, P. E., \& Richler, J. J. (2012). Effect size estimates: current use, calculations, and interpretation. Journal of Experimental Psychology: General, 141(1), 2.

George, D. \& Mallery, M. (2010). SPSS for Windows Step by Step: A Simple Guide and Reference, 17.0 update (10a ed..) Boston: Pearson.

Hoberg, A. (2009). Reducing performance anxiety in woodwind playing through the application of the Alexander Technique principles. Doctoral dissertation, University of Pretoria.

Işkın, S. (2018). Mesleki müzik eğitimi veren kurumlarda performans kaygısı ve öz-yeterlik algısının çalgı başarısına etkisi. Yayımlanmamış Yüksek Lisans Tezi, Marmara Üniversitesi Eğitim Bilimleri Enstitüsü, İstanbul.

Kalayc1, Ş. (2010). SPSS uygulamalı çok değişkenli istatistik teknikleri (5. Bask1). Ankara: Asil Yayın Dağıtım. 
Kenny, D. T., Fortune, J. M., \& Ackermann, B. (2013). Predictors of music performance anxiety during skilled performance in tertiary flute players. Psychology of Music, 41(3), 306-328.

Kim, Y. (2003). Effects Of Improvisation-Assisted Desensitization, And Music-Assisted Progressive Muscle Relaxation And Imagery On Ameliorating Music Performance Anxiety Of Female College Pianists. Doctoral Dissertation, The University of Kansas, A.B.D.

Kobori, O., Yoshie, M., Kudo, K., \& Ohtsuki, T. (2011). Traits and cognitions of perfectionism and their relation with coping style, effort, achievement, and performance anxiety in Japanese musicians. Journal of Anxiety Disorders, 25(5), 674-679.

Lorenz, S. R. (2002). Performance anxiety within the secondary choral classroom: Effects of the alexander technique on tension in performance. Master Dissertation, Michigan State University.

Mansberger, N. B. (1998). The effects of performance anxiety management training on musicians' self-efficacy, state anxiety and musical performance quality. Master Dissertation, Western Michigan University.

MEB. (2008). Anadolu Güzel Sanatlar Lisesi Türk ve batı müziği çalglları dersi (flüt) öğretim programı. Ankara: Devlet Kitapları Müdürlügüü.

Önder, G.C. (2013). Flüt eğitiminde nefes tekniği. Selçuk Üniversitesi Sosyal Bilimler Enstitüsü Dergisi, (29), 153-163.

Özmenteş, S. (2013). Çalg1 eğitiminde öğrenci motivasyonu ve performans. Eğitim ve Öğretim Araştırmaları Dergisi, 2(2), 320-329.

Rothlisberger, D. J. (1993). Effects of video modeling preparation on student instrumental audition performance achievement and performance anxiety. Doctoral dissertation, Maryland University.

Tabachnick, B. G., \& Fidell, L. S. (2007). Using multivariate statistics (5th ed.). Boston: Allyn and Bacon.

Tankız, K. D. (2016). Flüt öğretiminde birlikte çalma öğrenme biçiminin performans kaygısı ve motivasyon düzeyine etkisi, Yayımlanmamış Doktora Tezi, İnönü Üniversitesi Eğitim Bilimleri Enstitüsü, Malatya.

Turgay, H. H. (2002). Flüt eğitimi açısından nüans probleminin çözümünde teknik boyutun kavranmasının önemi. Yayımlanmamış Sanatta Yeterlik Tezi. İstanbul Üniversitesi Sosyal Bilimler Enstitüsü, İstanbul.

Umuzdaş, M. S. (2007). Gazi Eğitim Fakültesi Müzik Öğretmenliği Programı piyano öğrencilerinin vize ile final süreci arasındaki kaygı düzeylerinin başarı düzeylerine göre incelenmesi, Yayımlanmamış Yüksek Lisans Tezi, Gazi Üniversitesi, Eğitim Bilimleri Enstitüsü, Ankara.

Üstün, E. (2010). Eğitim fakülteleri güzel sanatlar eğitimi bölümleri müzik eğitimi ana bilim dallarında uygulanmakta olan bireysel çalgı flüt eğitiminde karşılaşılan teknik problemlerin incelenmesi. Yayımlanmamış Yüksek Lisans Tezi, Selçuk Üniversitesi Eğitim Bilimleri Enstitüsü, Konya.

Yağışan, N. (2009). A survey of music performance anxiety among Turkish music students. Turkish Journal of Music Education, 2(1), 1-11.

YÖK Öğretmen Yetiştirme Lisans Programları, (2018). Müzik Öğretmenliği Lisans Programı. https://www.yok.gov.tr/Documents/Kurumsal/egitim_ogretim_dairesi/Yeni-Ogretmen Yetistirme-Lisans-Programlari/Muzik_Ogretmenligi_Lisans_Programi.pdf. web adresinden 01.12.2019 tarihinde alınmıştır. 